BANCA D'ITALIA

E U R O S I S T E M A

Temi di discussione

(Working Papers)

Scars of youth non-employment and labour market conditions

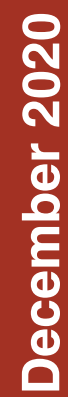

by Giulia Martina Tanzi
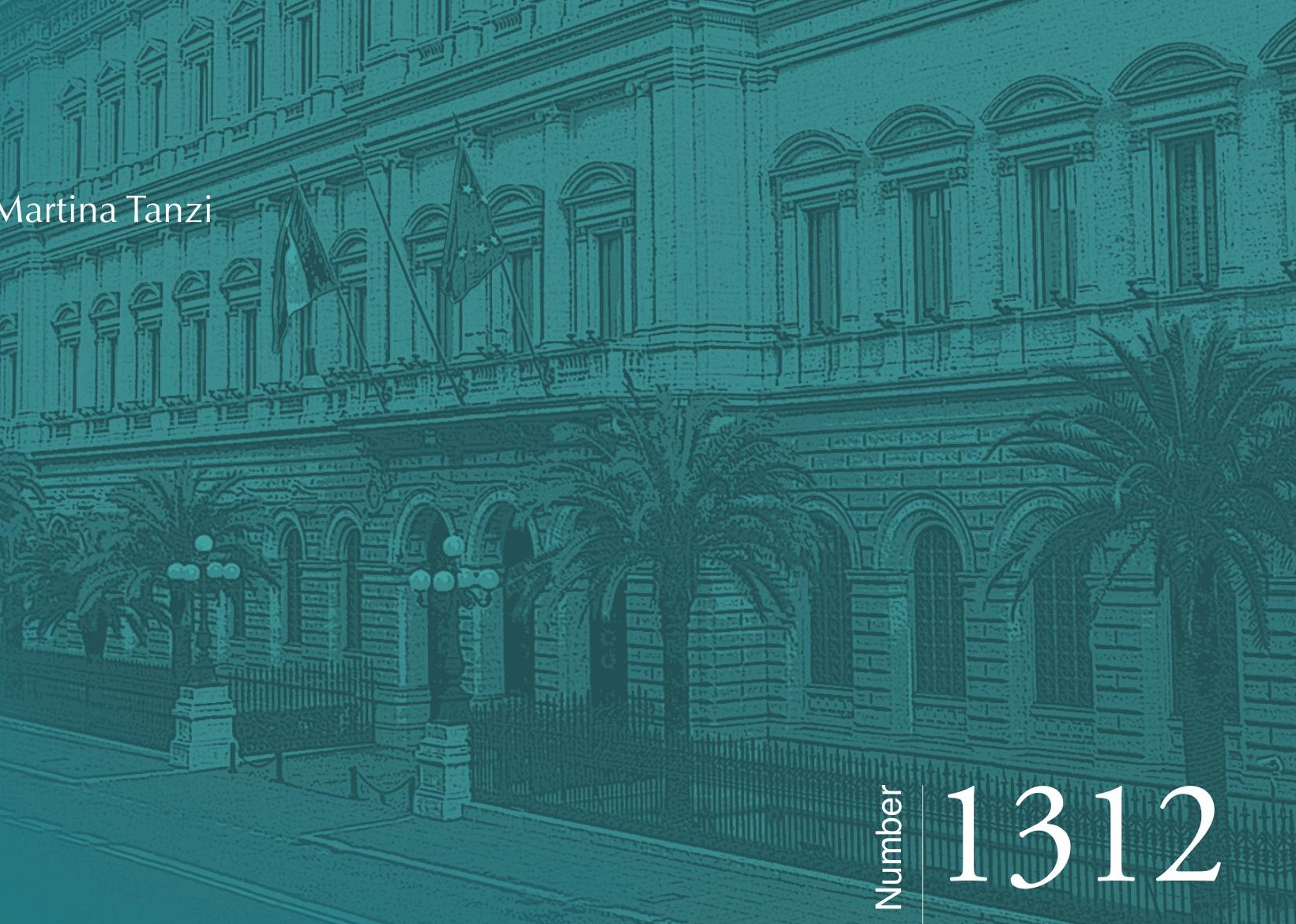



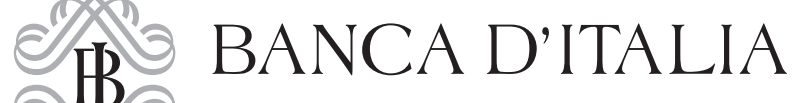

E UROS I S T EMA

\section{Temi di discussione}

(Working Papers)

Scars of youth non-employment and labour market conditions

by Giulia Martina Tanzi

Number 1312 - December 2020 
The papers published in the Temi di discussione series describe preliminary results and are made available to the public to encourage discussion and elicit comments.

The views expressed in the articles are those of the authors and do not involve the responsibility of the Bank.

Editorial Board: Federico Cingano, Marianna Riggi, Monica Andini, Audinga Baltrunaite, Marco Bottone, Davide Delle Monache, Sara Formai, Francesco Franceschi, Adriana Grasso, Salvatore lo Bello, Juho Taneli Makinen, Luca Metelli, Marco Savegnago.

Editorial Assistants: Alessandra Giammarco, Roberto Marano.

ISSN 1594-7939 (print)

ISSN 2281-3950 (online)

Printed by the Printing and Publishing Division of the Bank of Italy 


\title{
SCARS OF YOUTH NON-EMPLOYMENT AND LABOUR MARKET CONDITIONS
}

\author{
by Giulia Martina Tanzi
}

\begin{abstract}
In this paper I analyse whether non-employment periods at the initial stages of an individual's career may increase workers' propensity to experience non-employment also in subsequent years. The study is based on data on young individuals in Italy. The paper uses an instrumental variables approach to separate the effect of early non-employment from any residual unobserved heterogeneity. The results provide strong evidence of negative effects induced by early non-employment, but the size of these effects depends on individual and regional labour market characteristics. The negative repercussions of early non-employment are smaller during economic downturns or in regions with high unemployment rates.
\end{abstract}

JEL Classification: J64, C26, C34.

Keywords: non-employment, labor market conditions, instrumental variables.

DOI: $10.32057 / 0 . T D .2020 .1312$

\section{Contents}

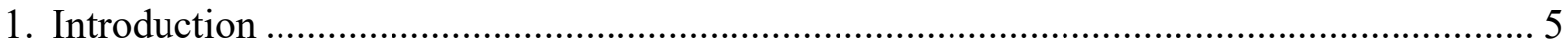

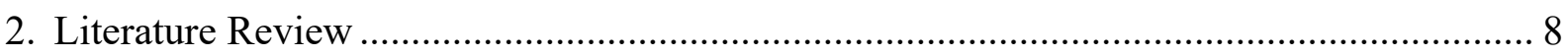

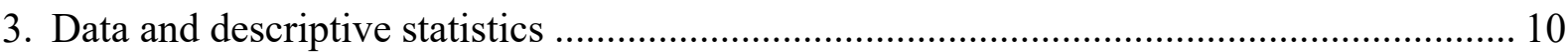

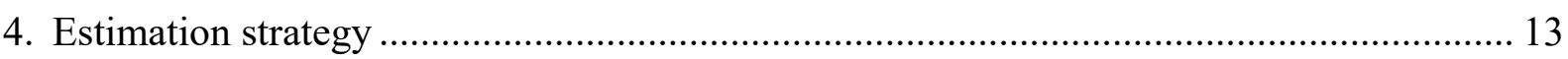

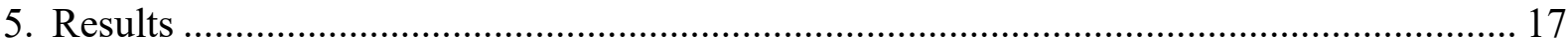

5.1 Heterogeneous effects: the role of labour market characteristics............................... 19

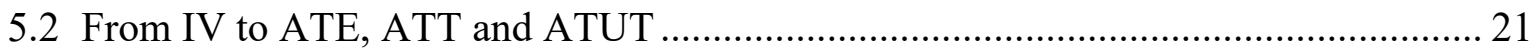

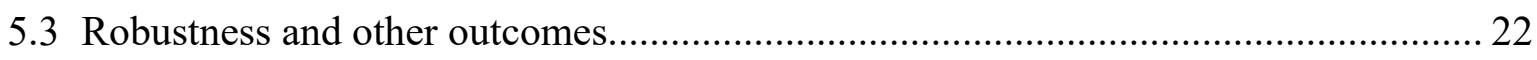

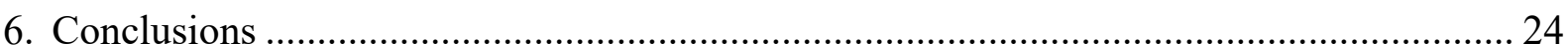

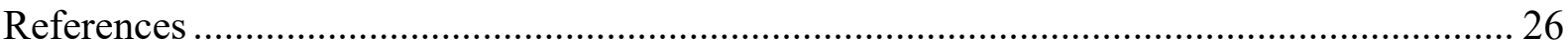

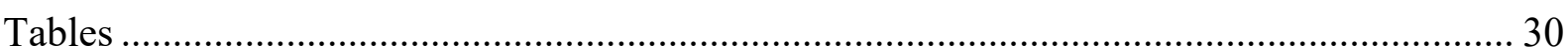

\footnotetext{
* Bank of Italy, Milano Branch, Economic Research Unit.
} 



\section{Introduction ${ }^{1}$}

The aim of this paper is to study whether a non-employment experience at the beginning of the career harms individual outcomes in terms of later non-employment. Using data on young individuals in Italy, I explore whether these adverse effects, commonly known in the literature as the scarring effects of non-employment, exist and if their magnitude varies across the country, depending on the regional labour market conditions. Understanding if the effects of early-career non-employment are lasting as well as their determinants is crucial in order to implement the necessary policy responses aimed at addressing school-to-work transition and targeted interventions early in peoples' careers, because of their effect in improving future employment chances too.

The empirical literature does not agree unequivocally on the existence and size of these scarring effects. In the United States there is little evidence that early nonemployment sets off a vicious cycle of recurrent non-employment (Heckman and Borjas (1980), Ellwood (1982), Corcoran and Hill (1985), Mroz and Savage (2006)). On the contrary, researchers have found stronger evidence of the adverse effects of nonemployment in Europe, but their magnitudes differ according to institutional and labour market conditions. For example, more pronounced scarring effects emerged in countries with a low level of youth unemployment and smooth school-to-work transitions (Brandt and Hank (2014); Kawaguchi and Murao (2014); Imdorf et al. (2019)).

Comparing the results obtained in different countries is not straightforward, due to several confounding factors and the availability of comparable data. The within country analysis conducted in this paper, which exploits regional differences in terms of the unemployment rate and its variations, may help in understanding the role of labour market conditions in influencing the magnitude of the scarring effects. Up to now, only a few works have investigated how much the scarring effects of non-employment vary within a country, over time or across regions (Biewen and Steffes (2010), Lupi et al. (2002)).

Why should we expect that an early experience of non-employment means longterm negative repercussions for young people's careers and that these repercussions vary according to the labour market conditions? There are three main theories that predict the existence of the scarring effects of non-employment. First, according to the signalling theory, employers have imperfect information about applicants and are unable to differentiate perfectly between persons with poor work skills from those with superior work qualities. For these reasons, they use past non-employment records as a signal of low or high productivity (Vishwanath (1989), Lockwood (1991), Gibbons and Katz (1991)). Second, according to the human capital models, early spells of nonemployment would deprive the individual of work experience during that part of the life

\footnotetext{
${ }^{1}$ I would like to thank Rosario Ballatore, Albrecht Glitz, Libertad Gonzàlez, Sara Pinoli, Tiziano Ropele, Diego Scalise, Marco Tonello and all the participants at the internal seminars of the Bank of Italy. The views expressed in the paper are those of the author and do not necessarily reflect those of the Bank of Italy.
} 
cycle that yields the highest return. This strong depreciation of human capital and loss of specific job skills result in high non-employment in later periods (Pissarides (1992), Acemoglu (1995)). Third, according to the job matching theory, non-employment periods may alter individuals' job application behaviour, making them more prone to accept unsuitable or poor quality jobs that are more likely to end or to be destroyed (Mortensen (1986)).

It is reasonable to assume that these mechanisms may work out differently according to the conditions of the relevant regional labour market (Omori (1997), Biewen and Steffes (2010)). As regards the first mechanism, based on signalling theory, the weakness of the labour market may influence the way in which employers interpret past non-employment records as a sign of individual ability. In regions with poor labour market conditions or in times of relatively high unemployment, past unemployment spells may not necessarily be perceived as a sign of low productivity and the disadvantage from having been unemployed may become smaller. So, the higher the regional unemployment rate or its variation, the less severe will be any adverse effect of past spells of non-employment of a given length in the evaluation of the job recruiter. On the contrary, according to the job matching theory, the scarring effects could be amplified in a weak labour market, because in this scenario individuals' discouragement increases as they become aware that it is more difficult to find a job. Finally, according to the predictions of the human capital theory, the labour market conditions should not play a part in the scarring effects: the amount of the human capital decay only depends on the duration of non-employment, but is independent of the labour market circumstances.

This paper explores the existence of the scarring effects in Italy and whether their magnitude depends on the heterogeneity over time and across regions in the labour market conditions. I draw on a sample of Italian administrative micro-data. These data contain information on all the contracts that were signed and terminated relative to a representative sample of workers born on 24 dates of the year, in the period 20092018. Italy is an interesting case for two reasons. First, Italy is one of the countries with the highest youth unemployment rate and one of the most rigid labour markets among OECD countries (Cockx and Ghirelli (2016)). If we consider the signalling theory, in rigid labour markets employers have more incentives to screen job applicants before hiring, because they are more forced into long-term relationships with their employees. Thus, we can reasonably expect that the early experience of non-employment may inflict considerable damage on young peoples' career (Kawaguchi and Murao (2014)). Second, Italy is characterized by a strong heterogeneity in social, economic and labour market conditions across regions, which I exploit in order to understand if the labour market conditions are relevant in generating variations in the scarring effects of early non-employment.

In order to estimate them, for each individual I computed the time spent in nonemployment during the first three years after the theoretical date of graduation (the early period) and in the subsequent six years (the later period). Empirical investigation poses a major methodological challenge because of endogeneity. While being able 
to control for many individual characteristics, there may still be determinants of the individual propensity to be non-employed that remain unobserved. It may be that individuals who are unemployed in one period are in this situation because they have characteristics that make them particularly vulnerable to unemployment, such as low levels of motivation, unfavourable attitudes or a general lack of abilities. The unemployment risk for future periods will also increase if these characteristics persist over time. Consequently, to avoid a spurious relationship between current and future unemployment, it thus becomes crucial to separate the differences in later non-employment, which are causally related to early non-employment, from the differences due to unobserved personal characteristics that are also correlated with early non-employment.

The paper uses an instrumental variable approach to distinguish the effect of early non-employment from any residual unobserved heterogeneity. In line with the previous literature, as instrument I use the regional youth unemployment rate in the last year of school or university, according to the individual level of education. In particular, I consider the unemployment rate of the 19-28 year age group to instrument the nonemployment duration of the individual with an high school diploma and of the 25-34 year individuals to instrument the non-employment duration for those individuals with a degree. The validity and the exogeneity of the chosen instrumental variable will be discussed in detail in Section 4.

The evidence suggests that the experience of youth non-employment may lead to penalties in terms of persistent non-employment: on average, every day of nonemployment during the first years of the professional career means an additional day of non-employment during subsequent years. This effect varies markedly according to individual characteristics: the scarring effects are smaller in the case of graduates (compared with individuals with a high school diploma). This may be due to the fact that for these candidates the role of the educational system is stronger in signalling the suitability of a job seeker for a particular job.

Then, in order to shed some light on the role played by labour market conditions on the magnitude of the scarring effects, I exploit the differences in the regional labour market conditions that existed within Italy in the years analysed. In particular, the southern regions had worse economic conditions than the North in terms of unemployment rates and of their variations. The results show that the past individual non employment experience is less scarring in regions with weak labour market conditions, i.e in regions with high unemployment rates and, mostly, in those regions that suffered increases in the unemployment rate. Therefore, the damage associated with past non-employment seems to be reduced if a worker is non-employed in an area that is suffering a downturn in economic conditions. This evidence of heterogeneity in the scarring effects according to the conditions of the regional labor market can easily be interpreted using the signalling theory. In fact, the scarring effects are lower in those regions where the experience of unemployment is considered part of a typical individual's labor market history and unemployment spells are not necessarily perceived as a signal of low productivity. On the contrary, as mentioned, these results are not consistent with the predictions of the other two theories at the basis of the scarring 
effect (job matching theory and human capital models).

The results obtained are important from a policy point of view. The existence of negative effects of early experience in non-employment strengthens the case for policies aimed at addressing school-to-work transition and at reducing the incidence of youth unemployment. Moreover, according to the evidence provided in this analysis, policy intervention for the young could be more effective in reducing the total costs of early non-employment if it targets less educated individuals, in the event of good cyclical conditions and in regions with low unemployment levels.

The rest of the paper is organized as follows: after a brief review of the literature, Section 3 presents the data and the main descriptive statistics. Section 4 describes the empirical strategy and discusses the identification issues, while the results are reported in Section 5. Section 6 concludes.

\section{Literature Review}

Only recently the literature has moved its focus from the duration dependence of non-employment, which consists in the reduction in the probability of leaving nonemployment as the duration of the spell lengthens, to the structural (or state) dependence. The structural dependence is the main focus of this analysis and it consists in the increase in the propensity to experience non-employment as the past spells of nonemployment increase. this means that experiencing non-employment in a given period may increase in itself the chances of suffering unemployment again in the future. These are the so called scarring effects of non-employment.

As mentioned, the existence and the size of the scarring effects of initial nonemployment on later non-employment are controversial ${ }^{2}$. As regard the European countries, strong evidence of significant and long-lasting scarring effects has been found in Britain (Gregg (2001), Arulampalam et al. (2000) for males), in Germany (Schmillen and Umkehrer (2017)) and in Northern European countries (Nilsen and Reiso (2011), Nordstrom Skans (2011)). Little or no evidence of the persistence of unemployment spells on the incidence and duration of future unemployment spells has been found mainly in the US setting (Heckman and Borjas (1980); Ellwood (1982); Mroz and Savage (2006)) but also in other works that focus on European countries (Eriksson and Rooth (2014)). These analyses suggested that the effects of initial non-employment experiences seem to die off very quickly and wash out after some interval because subsequent work experiences outweigh the evidence of an unfavourable past employment records. Other works reported adverse effects of past non-employment only on individuals with certain characteristics: Burgess et al. (2003) found a lasting adverse effect only on low-skilled individuals. This is explained by the fact that the more able,

\footnotetext{
${ }^{2}$ Some works focused on the effects of past non-employment on other outcomes: earnings and wages (Gregory and Jukes (2001); Gregg and Tominey (2005); Mroz and Savage (2006); Eliason and Storrie (2006)) and on long-lasting jobs (Cockx and Picchio (2012)).
} 
when facing a period of non-employment, are more likely to deepen their qualifications, becoming more attractive to employers.

Only few papers investigated empirically the variability in the state-dependence according to labour market conditions ${ }^{3}$. The most relevant works are Biewen and Steffes (2010), which considers the magnitude of the scarring effects according to cyclical conditions within Germany and Lupi et al. (2002), which estimates, as in my work, the existence of scarring effects of non-employment in Italy, focusing on the differences between the North and the South of the country. Both these two works found that the adverse effect of unemployment on later outcomes is lower during periods of economic downturn or in regions with high level of unemployment. This can be explained by the signalling theory: recruiters might be less careful about hiring applicants with any sort of early unemployment, since past unemployment is seen as a common experience 4. Differently from the two cited works, Ayllón (2013) reports the opposite evidence, stating that in countries with high unemployment the scarring effects are higher because individuals' discouragement may increase as the individuals are aware that it has become more difficult to find a job.

It is important to notice that there are several differences between my work and the paper of Lupi et al. (2002), which also focuses on Italy. First, in Lupi et al. (2002) the individuals are observed only over a two year period (1993-95) while in my work I can observe the individuals over a 9 year period. Their main dependent variable is the re-employment wage, while I consider the later non-employment experiences. Finally, in order to understand how much the labor market conditions are a key variable in shaping the effects of the past non-employment experience, they do simply interact the individual unemployment experience with North/South area dummies, while I consider the specific regional labour market conditions, such as the regional unemployment rates. For these reasons I believe that my work can provide a further contribution in better understanding the differences in the scarring effects within Italy.

Finally, this paper is related to another strand of literature that shows that the labour market conditions at graduation have a persistent impact on the labour market career of young graduates (among the others: Kahn (2010); Oreopoulos et al. (2012); Altonji et al. (2016)). The results of this literature are relevant to my methodology. For example, Burgess et al. (2003), Raaum and Røed (2006) and Cockx and Ghirelli (2016) use variation in aggregate unemployment at entry into the labour market to examine the impact of early labour market conditions on later unemployment of different cohorts. In my analysis, their main independent variable of interest, the unemployment rate in the last year of school, is used instead as an instrument for the early experi-

\footnotetext{
${ }^{3}$ Imbens and Lynch (2006) and Kroft et al. (2013) explored how local labor market affect the negative duration dependence of unemployment. The damage associated with being in a long spell of unemployment seems to be reduced somewhat if a worker is unemployed in an area with high overall unemployment.

${ }^{4}$ In a related paper, it has been shown that employers' recruitment strategies may change in response to different conditions on the relevant regional labour market (Russo et al. (2001)).
} 
ence of non-employment in order to correct for selective incidence of non-employment. Thus, in the choice of the instrument, I rely on the exclusion restriction that early non-employment is the underlying channel that explains the long term effects of the labour market conditions at the time of the end of the education.

\section{Data and descriptive statistics}

I use a representative sample of administrative micro-data of Comunicazioni Obbligatorie, which are available from 2009. From this year, whenever an employment contract is signed, terminated or changed, employers must electronically submit this information to the regional agency in charge of active labor market policies, which then forwards it to the Ministry of Labor. The administrative archive built on these communications therefore contains information on all the contracts that have been signed, terminated or changed starting from 2009. Obviously, this dataset does not cover selfemployment and hence the focus of this analysis is on payroll employment only. The Ministry releases a sample of micro-data relative to all workers born on 24 dates (the 1st and 15th day of each month). In this analysis I consider two cohorts of individuals that potentially completed their education and were available to enter the labour market in 2009 and in 2010, and I follow them for 9 years. I consider the first three years in order to compute the early non-employment duration, defined as the average yearly duration, in days, of the non-employment spells of each individual in the first three years after school (Period 1). I then consider the subsequent six years (Period 2 ) in order to compute the later yearly average duration in days of non-employment, which is my dependent variable. These time windows are chosen in order to be able to consider a long enough period for evaluating adult labor market outcomes and, at the same time, to capture the majority of individuals' transitions from education to work in Period 1, as explained later in this Section.

My sample of interest is composed of all the individuals at the age of the theoretical school-to-work transition, depending on the level of education reported (high school, 3 -year degree or 5-year degree). To identify the sample of those that potentially entered the work force in 2009 and 2010, I consider those that theoretically should have ended the education process in 2008 and 2009. In particular, for individuals with a high school diploma, I considered those who were born in 1990 and 1991, and that potentially finished high school in 2008 and 2009 (aged 19). In the same way, for 3-(5-) year graduate students, I considered those born in 1987 and 1988 (1985 and 1986): these potentially entered the work force in 2009 and 2010, having completed their degree the year before (aged 22 and 24). It is important to stress that the level of education of each individual does not change over time, because the data only report the highest level of education achieved, recorded in 2019. So, in order to select the sample correctly , I consider, for example, only those born in 1990-91 that in 2019 still have a high school diploma as the highest level of education. On the contrary, in the sample, I do not

consider those individuals born in 1990-91 that in 2008, having completed high school, started and obtained a degree. 
Unfortunately the data do not show the exact time of the end of their education but only the level of education of each individual. These data limitations may generate some measurement errors in my main variables of interest because I consider the theoretical date of graduation rather than the actual one. Since the data do not allow us to distinguish correctly between individuals who finished school on time and were not able to find a job from those who did not end education on time and were not looking for a job and from those who started a degree program for example, and decided to drop out. However, from the perspective of an employer, having been unemployed for the entire Period 1 or having finished school late is, in the same way, a signal of low productivity and it may equally generate scarring effects. These, in fact, are years of potential work experience that the individual loses because of non-employment or because of the delay in completing education. The signalling theory at the basis of the scarring effects can thus also refer to effort and ability in education.

As mentioned, I considered the first three years after the theoretical end of the school in order to compute the individual early duration of non-employment. Data show that around $25 \%$ of the individuals started a job within the first year after the potential end of school, another $20 \%$ in the second and $15 \%$ in the third year, while the remaining $40 \%$ only entered the labour market only in Period $2^{5}$. This large fraction of individuals that has not been employed for the entire Period 1 explains the high average value of the early duration of non-employment, as shown in Table 1. However, since the percentage of entrants drops consistently starting from the fourth year and shows a decreasing trend year after year, I chose to consider a three-year window for Period 1, in order to have a sufficient number of individuals that were also employed in Period 1 but, at the same time, to have a enough time over which the variable is observed in Period 2. There may be two different reasons for these very high values of non-employment in Period 1. First of all, the slow and hard school-to-work transition that characterizes Italy, linked to the failure of the education and training systems to deal with and overcome the lack of general and job specific work experience (Pastore (2019)). Second, these high values of early non-employment can also be related to the measurement errors in the non-employment variables relating to the fact that the data do not show the actual timing of graduation. The difference between the theoretical and the actual time of the end of education may be significant especially for graduates. In fact, according to the National Agency ANVUR, for the last cohorts of 3year graduates the percentage who graduate on time is around 50 per cent, with strong differences throughout the country. After 6 years, the percentage of graduates increases to $80 \%$. This means that the almost all the 3-year graduates may potentially enter the labour market in the Period 1 time window. The percentage of people who repeat at least one year of secondary school is, on the contrary, quite low and equal to around $9 \%$ in the period of my analysis.

\footnotetext{
${ }^{5}$ The percentage of entrants within 3 years does not significantly differ between individuals with high school diploma or degree.
} 
As regards the dependent variable, in order to have the best representation of the propensity to experience non-employment in Period 2, the duration of non-employment is computed on the remaining six years, the maximum period available in the data. Considering smaller or partial time periods would not make much sense in this analysis, because it would give a partial and incomplete view of the individual history of non-employment and employment experiences. In Period 2, the data show that, on average, the individuals were non employed for 195 days in each year (Table 1). Only around $10 \%$ of the sample has been employed for the entire period 2 and for these, the non-employment duration in Period 2 is set equal to 0 . On the contrary, around $8 \%$ was non-employed during the whole of Period 2, and for them the yearly non-employment duration in Period 2 is set equal to 365 days. Thus, the dependent variable is censored from below at the minimum feasible value $(0)$ and from above (the maximum value is 365). To take the distribution of the dependent variable into account, I supplement the standard OLS regressions with Tobit regressions, the most appropriate model for continuous responses where the outcome variable is censored. Moreover, the statistics show great variability in the duration of the non employment experience in Period 2 according to the education and the prevalent sector of work (Table 2). The highest values of non employment spells are registered for individuals with a high school diploma and for those that work in agriculture and in some specific services. The lowest values of non-employment are found for graduates and for those working in financial services and manufacturing ${ }^{6}$. Table 3 shows the average length of non-employment in Period 2 according to the region of work and the cohort, with significant differences across regions.

Table 4 shows an easily identifiable correlation between non-employment during the first three years and in the subsequent six years (column III). Moreover, a positive correlation is also shown between the duration of early non-employment and the probability of being non-employed at the end of Period 2 (column IV) and job instability, measured by the number of contracts that ended during Period 2 (column V). These variables will be considered as additional outcome variables in the analysis.

A part from the CICO dataset, I also used the Labour Force Survey (LFS) in order to compute the regional labour market conditions in Period 2, necessary as control variables. In particular, I computed the regional unemployment rate in the region of work at the beginning of Period 2 and according to the level of education, the percentage variation in this regional unemployment rate between the last and the first year of Period 2, and the percentage variation in the stock of employed individuals (15-64) in the same region, in the same sector and with the same individual level of education. Moreover, the LFS provided me with the youth regional unemployment rate for years 2008 and 2009 in the region of birth, which I used as an instrument for

\footnotetext{
${ }^{6}$ The considered sectors are: Agricolture and Fishery, Manifacturing, Construction, Wholesale and retail trade, Transport, Information and communication, Financial services, Real estate and business services, Public administration, Education and Health care, Other services
} 
early individual non-employment ${ }^{7}$.

\section{Estimation strategy}

The individual later non-employment experience, measured in Period 2, can be driven by the individual's early non-employment history, by the individual characteristics and by the local labour market conditions. I estimate the following equation, where subscript $\mathrm{i}$ indicates the individual, $\mathrm{c}$ the cohort, $\mathrm{r}$ is the prevalent region of work, $\mathrm{d}$ is the level of education (degree or high school diploma). $\mathrm{T}$ is the moment in which every variable is considered: $t_{1}$ is the time window in which we measure early non-employment (first three years) and $t_{2}$ is the time window in which we measure later non-employment (subsequent six years).

$$
\begin{aligned}
& \text { NonEmp }_{\text {crddt }_{2}}= \\
& \alpha+\beta \text { onEmp }_{i c r d t_{1}}+\gamma I N D_{i c r d}^{\prime}+\delta F_{\text {crdt }}^{\prime}+\eta R_{r}^{\prime}+\kappa C_{c}^{\prime}+\iota D_{d}^{\prime}+\lambda R C_{r c}^{\prime}+\epsilon_{\text {icrdt }}
\end{aligned}
$$

where NonEmp are the average days per year spent in non-employment. IND is a set of time invariant individual characteristics, which comprehend sex, age squared, a dummy equal to 1 if the individual starts to work before the end of the school, a dummy equal to 1 if region of birth is different from the region of the first work and a dummy variable for the prevalent sector of work in Period 1. Moreover, I included the job qualification (low, medium, high) and the entrance wage of the first job, which can be seen as a proxy of individual ability. $F_{t_{2}}$ are the regional labour markets conditions in Period 2 that comprehend, for individuals that work in region $r$ and with education $\mathrm{d}$ and that belong to cohort $\mathrm{c}$, the unemployment rates at the beginning of Period 2 , the variations in this unemployment rate between the beginning and the end of Period 2 and the percentage changes in the number of employed individuals in the prevalent sector of work of the individual. These variables capture both the supply and the demand of work that is relevant for the individual (similar workers in terms of region of work, education and sector). $R_{r}, C_{c}$ and $D_{d}$ are regional, cohort and level of education dummies; while $R C_{r c}$ are the interaction terms between the region of work and the cohort dummies.

$\beta$ is the coefficient of interest and it represents the effect of a one day increase in the number of yearly days spent in early non-employment on the number of yearly days spent in non-employment in later years. If $\beta$ is greater than 0 , other things held constant, individuals who experienced non-employment in the early period are more

\footnotetext{
${ }^{7}$ Notice that LFS do not provide data for the region Val D'aosta in 2008. Consequently, I have to drop the individuals born in that region (5,513 observations).
} 
likely to be non employed in the later period, i. e. there is a state dependence effect or scarring effects of non-employment.

In order to capture correctly the long-term effects of early non-employment it is necessary to distinguish differences in the later non-employment that are causally related to early non-employment from the differences due to unobserved personal characteristics (for example, ability or motivation) that are correlated with both early and subsequent non-employment. It is reasonable that different individuals are more vulnerable to unemployment both in early and later stage of the career because of some unobserved characteristics. If these characteristics are not properly controlled for, we run the risk of getting a bias in the estimate of the magnitude of the coefficient of interest.

A number of methods has been used in the literature to handle the endogeneity issue. Some studies rely on exogenous events (Jacobson et al. (1993), Farber et al. (1993)); others use propensity score matching to reduce worker heterogeneity or sibling data (Nilsen and Reiso (2011); Nordstrom Skans (2011)); another study conducted a field experiment with fictitious job applications to employers (Eriksson and Rooth (2014)). My work draws on the use of an instrumental variables approach. A valid instrument must determine causally the early non-employment experience (validity) and must be exogenous to the individual (exogeneity). In the related literature, the instruments used for the early labor non-employment were local unemployment at age 16 , the age at which the entry into the labour market can first take place (Gregg (2001); Gregg and Tominey (2005)), the variation in the unemployment rate faced by young people (Neumark (2002)), the the provincial unemployment rate at graduation (Ghirelli (2015)) and the firm-specific labour demand shocks (Schmillen and Umkehrer (2017)).

In line with the previous literature, as an instrument for the duration of the early spells of non-employment, I use the youth' unemployment rate in the region of birth of the individual and in the last year of school/university, before the individual's entry into the labor market. In particular, I consider the unemployment rate of the 19-28 year age group as instrument for the duration of early non-employment of the individuals with a high school diploma, and the unemployment rate of the 25-34 year age group for the individuals with a degree. Thus, there are three main sources of variation in the instrument: longitudinal variation (cohorts that potentially entered in the workforce respectively in 2009 and 2010), regional variation and education level.

As regard the validity of the instrument, the state of the labor market at the time of the individual potential entry may directly affect the labor market experience of those who are ready to enter. Difficult entry conditions may lead to a disorderly entrance with long early spells of non-employment, influencing the likelihood of finding and keeping a job. Unfortunately, the data do not report the region where the individual completed his/her education, which is likely to be the region where the young starts to look for a job, but only the region of birth. This may entail some measurement errors: if many individuals get the diploma or obtain the degree in a different region with respect to the one of birth and start looking for a job in this region, the validity of the instrument is reduced, because the unemployment rate measured in the region of birth 
is not able to capture the early economic conditions the individual really faced. The only other information available in the data is the region where the first job has been signed. However, the choice to use the unemployment rate in the region of birth with respect to the one measured in the region where the first job has been signed helps in reducing the more consistent problem of endogenous migration and spacial sorting, i.e. the fact that individuals sort into regions according to unobservable characteristics in order to have more job opportunities. Since the validity of the instrument can be tested, while this is not the case for exogeneity, I prefer to use the unemployment rate of the individual region of birth, for which a convincing case for exogeneity can be made. However, in the robustness section, I will show the results obtained also using as instrument the unemployment rate of the region where the first contract is signed.

The second condition that the instrument has to fulfill is the exogeneity condition. The labour market conditions in the last year of school/university and in the region of birth are exogenous to the individual unobserved characteristics, generating variation in early job non-employment that is unrelated to unobserved factors that may jointly influence early and later non-employment. It is worth to notice that the unemployment rates in the last year of school, used as an instrument, refer to the year 2008 for the first cohort and to 2009 for the second cohort. In these years of Great Recession the cyclical Italian situation turned bad rapidly for the vast majority of firms and the principle factor at the basis of the reduction in GDP was the drop in exports (Caivano and Siviero (2010); Bugamelli and Zevi (2009)). Thus, the crisis was non anticipated but imported from abroad and this guarantees a great and exogenous variability in my instrument.

However, some issues should be kept in mind. The exogeneity assumption implies that any indirect effect of the instrument on Y occurs uniquely through the endogenous regressor. First, if the local labour conditions are strongly persistent, there might be a correlation between later individual non-employment and the instrument, other than through the first stage. To avoid this, it is crucial to properly control for local unemployment conditions in the second period (Gregg (2001); Neumark (2002)). As mentioned, I inserted controls for regional conditions, which capture both the demand and the supply of work. Another violation of the exclusion restriction may be due to differences in institutions or in regional labor market policies that could be correlated both with the instrument and with the outcomes. Including regional dummies and the interactions between the cohort and the regional dummies helps to capture both permanent or time-varying regional differences, which may be correlated with the instrument and the outcomes. Another possible violation of the exogeneity assumption refers to the fact that the local labour market conditions before graduation may affect also the quality of the first jobs and not only the early duration of non-employment. In fact, students who finished school during downturns would not only experience higher early non-employment, but could also accept lower-quality jobs with higher probability with respect to those who graduate during favorable times. Thus, there may be an additional channel that links the early labour market conditions and Y. However, I believe that this channel would have been predominant if my analysis was focused 
on the effects on wages. In fact, a poor quality job in the first years mainly affects the quality of future jobs and thus the wages, but not necessarily the non-employment duration. Thus, I think that early non-employment is the main driver that explains the long term effects of the labour market conditions at the time of the end of the education.

The exogeneity assumption also requires that the unemployment rate at the time of the potential entry the labour market does not affect the unobserved composition of new entrants by year and region. To rule this risk out, one has to assume that students choose the moment of graduation or the moment to finish high school independently of the business cycle. This issue does not appear particularly relevant for individuals with a high school diploma, which have less margins to postpone the end year of school. Also for graduated individuals, several works do not find evidence that labor market conditions affect the individuals' choice of educational attainment (Raaum and Røed (2006), Ghirelli (2015) ${ }^{8}$. Moreover, as mentioned, in this analysis the duration of early non-employment coincides with the number of days of potential experience that have been lost from the theoretical moment of the end of the school, independently from the fact that the individual has completed their education and he was looking for a job or if he has decided to postpone its end. Consequently, this concern seems to apply less in this setting. However, if poor labor market conditions lower the opportunity costs associated with accumulating more schooling and affect schooling decisions, the exogeneity assumption may be violated, generating selectivity problems.

The OLS bias can go in both directions. If unobserved individual characteristics are likely to be negatively correlated with both early and subsequent non-employment (like ability and motivation), this will upwardly bias the OLS estimates of the coefficient of interest. However, there may be a a downward bias if the unobservables are positively correlated with early non-employment but negatively correlated with later non-employment. For example, omitting information on unobserved differences in individuals jobs search behavior (orthogonal to ability and motivation) might introduce a downward bias. New entrants to the labor market need to discover their own skills and preferences as well as the opportunities available to them. If the returns to search are higher for some individuals, these may spend more time searching in early stage and this will extend time during which they are unemployed in the first years on the labour market but it will also make them more successful with theirs search efforts, with more stables matches in adult period. Up to now, all the works in the literature are in favour of this latter hypothesis (Gregg (2001); Neumark (2002); Gregg and Tominey (2005); Ghirelli (2015); Schmillen and Umkehrer (2017)).

Finally, since the instrumental variable is a grouped variable that does not vary at individual level, a correct inference requires to use cluster-robust standard errors,

\footnotetext{
${ }^{8}$ In particular, Ghirelli (2015) shows that the choice of graduation is independent from the labour market conditions: the duration between the end of compulsory education and each year of potential graduation is independent to the provincial unemployment rate in those years.
} 
clustered at the level of the region of birth, education and cohort (Moulton (1990); Angrist and Pischke (2008)).

\section{Results}

Table 5 reports the results for the main variable of interest. The OLS regression shows a statistically highly significant coefficient for the early duration of nonemployment, equal to 0.44: each additional day of yearly non-employment during the first three years increases non-employment in the following six years by half a day per year. Since the dependent variable is censored, I also applied the maximum likelihood estimation of a Tobit model. In the Tobit specification the marginal effect of early non-employment is in line with the coefficient found in the OLS regression: the average marginal effect of early-career non-employment is about 0.55 days. This means that the linear method provides a good approximation of the coefficient of interest. The results of the OLS and Tobit models demonstrate, as also emerged in the descriptive statistics, which early non-employment is a good predictor of subsequent non-employment. Other important variables in influencing, all things being equal, the duration of later non-employment are the level of education and the qualification (Table 6): individuals with lower education levels and lower qualifications experience more non-employment in period 2. Those individuals who moved from their region of birth in order to find a job and who worked during school also have greater probabilities to experiencing longer non-employment periods.

Column III of Table 5 shows the results of the IV estimates: in the bottom part of the Table the coefficients of first-stage estimates indicate that individual early nonemployment is statistically and positively correlated with the regional level of unemployment measured in the last year of school and in the region of birth. The F-statistic, bigger than the standard threshold, also assesses the validity of the instrument. The second stage estimate shows that the average amount of later non-employment that is induced by an additional day of early non-employment is statistically highly significant and equal to 1.03. The Tobit-IV regression (Column 4) shows a similar coefficient, equal to 1.01. therefore, the IV regression also shows that non-employment is rather

persistent during the individual career. With one day of early non-employment leading to around 1 additional days of joblessness in the following years, the scarring effect appears to be economically important because of its effect in reducing later employment chances. The magnitude of the IV coefficients are consistent with the existing literature that considers similar specifications and variables. For example, Schmillen and Umkehrer (2017) found that in Germany, each additional day of unemployment during the first eight years on the labour market increases unemployment in the following 16 years by half a day.

My results suggest that the OLS estimates are downward biased, as found in Gregg (2001), Neumark (2002) and Schmillen and Umkehrer (2017). The downward bias is explained by the fact that unobserved characteristics are positively correlated with $\mathrm{x}$ but negatively correlated with $\mathrm{y}$, and can be related to individual heterogeneity in 
returns to search. However, in the interpretation of the results, as always with instrumental variable approaches, caution should be exercised in drawing strong conclusions until complementary evidence using alternative identifying assumptions is found. For this reason, in Subsection 5.3, I explore the sensitivity of the results to using the unemployment rate as an instrument in different forms. Moreover, it is also fundamental to remember that while the OLS estimates describe the average difference in later non-employment for those whose early non-employment differs by one day, the IV estimate is the effect of increasing the duration of early non-employment only for the compliers, a sub group of the population whose early non-employment was affected by the instrument. These estimates identify the local average treatment effect (LATE), which is representative for compliers and that depends heavily on the instrumental variable used. If compliers are a peculiar group, then LATE may not be interesting and may not answer an economic policy question. For this reason, in Subsection 5.2 I will also compute other parameters for the other economically interesting groups of the population (ATE and ATT).

In order to have a better understanding of the phenomenon, I tried different forms of the independent variable. In fact, it could be that the first spell of non-employment is the most relevant one in influencing the subsequent work path, creating a vicious circle. For this reason, I considered the amount of days spent in non-employment during the first period of non-employment during Period 1, instead of the total number of days spent in non-employment during Period 1. In addition, I also considered the maximum duration of the non-employment periods experienced in Period 1, since it can happen that very long spells of non-employment may have worse consequences on the next employment chances, because they constitute a marked and bad sign on the productivity of the worker or because they constitute a lost of human capital. These two variables (duration of the first non-employment spell and duration of the maximum non-employment spell in Period 1) are both strongly correlated with the total duration of non-employment and the results of the IV regressions show that they are both important in influencing the total duration of non-employment in Period 2, since their coefficients are positive and statistically significant (results available on request).

In this last part of the section I will explore whether the scarring effects vary according to some characteristics of the individuals. Table 7 reports the different IV coefficients according to gender (columns I and II), the level of education (columns III and VI) and qualifications, which are split into low/medium and high (columns $\mathrm{V}$ and VI). As regards gender, there are no significant differences between the scarring effects for males and females, since the stimated coefficients are similar. On the contrary, the scarring effects appear to be stronger for individuals with a high school diploma, with respect to those that have a degree. This confirms the results in Burgess et al. (2003) who only found an enduring adverse effect for the unskilled individuals. Infact, in line with signalling theory, employers can better infer information about graduate candidates' abilities from their college credentials. This helps employers in distinguishing between candidates and may reduce the impact of the signal that comes from their individual past history of non-employment. On the contrary, these results are not in 
line with the prediction of the HK theory. In fact, the more skilled, high educated and trained workers, such as those with a degree, are more likely to suffer from larger human capital deterioration during unemployment periods. This would translate into stronger scarring effects for graduate individuals. When I differentiate among individuals with different job qualifications, the scarring effects are found to be lower for highly qualified individuals, for which, again, the available objective signals of their ability are stronger.

\subsection{Heterogeneous effects: the role of labour market characteristics}

The aim of this section is to understand if there are differences in the magnitude of the scarring effects according to the specific regional labour market conditions. In fact, Italy is characterized by a strong heterogeneity in social, economic and labour market conditions among regions.

In particular, I consider the unemployment rate in the region of work for individuals with education $\mathrm{d}$ at the beginning of Period 2 and the change in the unemployment rate in the region of work for individuals with education d during Period 2 (Table 8) as contemporaneous labor market conditions. The choice of these indicators is in line with other works in the literature that exploit labour market differences. For example, in order to show how the dependence duration of non-employment varies according to the cycle, Kroft et al. (2013) used the median unemployment rate, the median ratio of vacancies to unemployment and the change in the unemployment rate, while Biewen and Steffes (2010) and Ayllón (2013) use the deviations of the unemployment rate from its linear time trend.

In order to correctly estimate the impact of these conditions on the scarring effects, I generate interaction terms between the early non-employment and these two variables, which are inserted one by one into the specification. The interaction term is treated as a second endogenous regressor; in this case, the instrument needs to be interacted with the exogenous part of the interaction to achieve identification (Wooldridge (2010); Bun and Harrison (2019)). Some concerns about the exogeneity of the contemporaneous local labour market conditions with respect to the individual may arise in the event of of selective mobility, which may arise if workers with certain unobserved characteristics offset the scars of early non-employment by moving or commuting to regions where there are more job opportunities. However, the percentage of individuals who changed regions for work motives from Period 1 to Period 2 and during Period 2 are equal, respectively, to $5 \%$ and to $6 \%$, very small fractions of the sample. The fact that the analysis is conducted on a regional basis (instead of at provincial or municipal level) strongly reduces the problem of endogenous migration.

Columns I and II show respectively the results of the IV regressions where I included, one by one, the interaction terms. The differences between the predictions of the theory occur in the sign and in the significativity of the interaction terms. According to signalling theory, the interaction terms should have non-zero and negative effects. In fact, we expect that the stigma effect of past non-employment is less severe in regions with poor labour market conditions: an increase in the unemployment rate 
and in its variation should be associated with a smaller effect. On the contrary, the coefficients of the interaction terms should be positive according to the job matching theory: in a weak labour market individuals' discouragement increases as they become aware that it is more difficult to find a job and consequently the adverse effects of past non-employment should create a stronger vicious cycle with greater effects on the current non-employment spells. Finally, the human capital model predicts that the coefficients of the interaction terms should be zero. In the bottom part of the table the first stage results of both the endogenous regressors are displayed. The F statistics and the Kleibergen Paap statistics suggest that the instruments are not weak.

The coefficients of the interaction term are significantly different from zero and negative when we consider both the unemployment rate at the beginning of Period 2 and its variation. This means that the past non employment experience is less scarring in regions with high unemployment rates and in regions that suffered increases in the unemployment rate. In these labour markets, it may be the case that employers recognize that this signal is less informative about worker' productivity because experiencing unemployment is more common among workers. Hence, the adverse impact of unemployment experience is relatively lower. On the contrary, firms are more suspicious about the past individual experience of non-employment when the average regional unemployment rate is lower or if the cyclical conditions are good. As mentioned, the evidence should have been in the opposite direction according to the job matching theory. Under the human capital decay hypothesis, none of the interaction terms should have had an effect because the amount of human capital decay should only depend on the duration of past non- employment, but not on the current circumstances.

The magnitude of the interaction's coefficient is quite small when we consider the initial rate of unemployment as labour market condition. This may be related to the fact that differences in the level of unemployment over time and across regions are mostly picked up by the cohort and the regional dummies and by the interaction between these two. In contrast, the coefficient is greater in magnitude when considering the interaction term between the past individual non-employment and the variation in the unemployment rate. This suggests that the magnitude of the scarring effects is particularly related to the variations in the current regional unemployment rate. The disadvantage from having been non-employed in the early period of the career is smaller in times of relatively large increases in unemployment.

In this analysis, following Biewen and Steffes (2010) and Ayllón (2013)), I allow the effect of work history to depend on the current labour market conditions. The intuition behind this is that employers seem to tolerate longer past search durations when the general unemployment rate is high, while they become stricter when general unemployment is low. However, other works do consider the past conditions in which the past non-employment spell occurred (Omori (1997), Mooi-Reci and Ganzeboom (2015)). In fact, Omori (1997) argues that the effect of past unemployment spells on the length of future unemployment spells should depend on the circumstances under which past unemployment occurred and not on the current conditions. The argument would be that employers discount past unemployment if it was experienced in times 
of difficult labor market conditions and consider it more negative if it was experienced when finding a job was relatively easy. As a robustness check, I interacted the individual non-employment spells with labour market conditions in Period 1 (Columns III and IV). My results show that the specific circumstances in which past unemployment spells occurred are not relevant in determining the size of these effects, differently from the contemporaneous conditions. This is in line with other findings in the literature (Biewen and Steffes (2010); Ayllón (2013)), which confirm the importance of the contemporaneous labour market conditions. These results may be explained by the fact that for the recruiter it is difficult to remember exactly the past labor market conditions in which past non-employment occurred. On the contrary, when screening job applications in their evaluation they do consider the current conditions.

\subsection{From IV to ATE, ATT and ATUT}

As mentioned, the IV estimates identify the local average treatment effect (LATE), which is strongly defined by the instrumental variable used and they are representative for compliers. If compliers consitute a peculiar group, then the IV estimates have strong "internal validity" (identification of a causal nexus for specific groups) but may have little "external validity" for the entire population. Moreover, the conventional ways of exploiting continuous instruments identify one overall IV effect that may be difficult to interpret and may hide interesting patterns of potential heterogeneity in returns. To identify parameters for the other economically interesting groups of the population, I will turn to the Marginal Treatment Effect estimation (MTE), as explained in Cornelissen et al. (2016). Such a framework produces a more complete picture than the conventional instrumental variable analysis, since it allows the identification of a variety of treatment parameters such as ATE, ATT and ATU, which are defined independently of any instrument. In fact, ATE is the average causal effect that allows to learn about the "typical" causal effect in a population; ATT measures how those individuals with observed characteristics that are currently enrolled in the treatment benefit from it on average and ATU, on the other hand, answers the question how those individuals with observed characteristics, who are currently not enrolled, would benefit on average from treatment if they participated. The sparse research on heterogeneity in scarring effects typically focuses on the heterogeneity in observed characteristics or in estimating quantile treatment effects (as in Schmillen and Umkehrer (2017)), rather than marginal treatment effects.

In the framework of this analysis, in order to compute MTE, it becomes necessary to move to a binary independent variable, which takes value equal to 1 if the duration of early unemployment exceeds the median value of the sample and 0 otherwise. Thus, $\operatorname{ATE}(\mathrm{x})$ measures how much individuals with observed characteristics $\mathrm{Xi}=\mathrm{x}$ would be penalized on average from experiencing high early unemployment if everybody with these observed characteristics had high early unemployment. In other words, it measures the expected effect if some individuals from the group of individuals with observed characteristics $\mathrm{xi}=\mathrm{x}$ were randomly experienced high early unemployment. ATT captures how those individuals with observed characteristics $\mathrm{Xi}=\mathrm{x}$ that experienced high 
early unemployment have been penalized from it on average, while ATU, on the other hand, measures how much those individuals with observed characteristics $\mathrm{Xi}=\mathrm{x}$ who did not experience high unemployment would have been penalized on average from experiencing high early unemployment.

Before moving to the MTE, it is necessary to compute the results of a IV estimate with the same binary independent variable, in order to be able to compare the results obtained. This IV estimate shows a coefficient equal to 237: the effect of having experienced high non-employment when young coincides with 237 days more of nonemployment in the subsequent years. This is completely in line, as expected, to the LATE coefficient, which is equal to 227. The ATE is slightly larger and equal to 255: the relative size of ATE with respect to the LATE depends on what individuals are shifted into treatment by the instrument and what individuals have higher or lower treatment effects. Since ATE is pretty similar to LATE, it is possible to conclude that these IV estimates have a strong external validity, because they well approximate the average treatment effect. Results also show that the ATT (effect on those individual that experienced high non-employment in the first years) is much larger than ATU, the effect that I would have observed on individuals with low early low non-employment if they would have experienced early high non-employment.

\subsection{Robustness and other outcomes}

In this Subsection, I explore the sensitivity of the results to using, as a instrument, the unemployment rate in different forms (Table 9). Then, I discuss the effect of the duration of the early spell of non-employment on a range of other labour market outcomes (Table 10).

I firstly used a different form of the baseline instrument, specifically the unemployment rate in the area of birth, instead of the rate measured in the region of birth (column II). This measure allows to remove in the instrument a great part of the crossregional variation within a year that is more prone to endogeneity bias from migration and residence decisions. Results are confirmed since the coefficient of interest is completely in line with the baseline one (0.89, instead than 1.03). Second, I show that the results hold, using as an instrument, the unemployment rate measured in the region where the first contract is signed, instead of the unemployment rate of the region of birth (Column II). The choice of this instrument may potentially violate the exogeneity condition, if individuals sort into regions according to unobservable characteristics in order to have more job opportunities. The coefficient of the duration of the early non-employment duration is statistically significant and slightly larger than the one found with the baseline IV specification (1.44).

In Columns III and IV, I move back to the standard specification but I use a restricted sample of observations. In particular, I excluded those individuals that did not enter the labour market in the whole Period 1. These may be individuals that did not find a job for the entire period or individuals that were still in education because of a large delay in graduation. When we exclude these, we find a smaller effect both in OLS and in the IV regressions. This means that the scarring effects vary considerably 
across the distribution of early non employment and that these are smaller when we exclude the individuals in the right tail of the distribution.

In this second part of the section I move to understanding if past non-employment affects other outcomes of the later individual job experience. This gives a more comprehensive view of the long-term consequences of the early non-employment for the workers. In particular, I consider the effect of the early non-employment on three different outcomes.

The first outcome considered is the job instability in the later years of the career, which is proxied by the number of contracts that terminated in Period 2. This may help in understanding whether the increased availability of temporary jobs, associated with frequent spells in unemployment when young, facilitates the integration in regular stable employment or spurs the development of a secondary labour market, in which the most vulnerable workers get trapped in a cycle between temporary dead-end jobs and unemployment. The evidence points out that an additional day of non-employment in the early period is statistically and positively correlated to job instability, but the magnitude of the coefficient is very small.

In addition, I consider the effect of past non-employment on wages. In particular, I consider the initial wage of the last contract that has been signed in Period 2. I am aware of the fact that selection into employment is non-random due to some observable or unobservable factors. This may bias the results if those who were employed at least once in Period 2 constitute a positively selective group of individuals. In principle, Heckman's selection model is the appropriate approach to address selectivity (Heckman (1979)). Unfortunately, I do not have a valid exclusion restriction for the selection equation. To avoid selectivity in wages, I set the wage equal to zero in case of nonemployment, as if earnings were censored. This allows me to estimate unconditional effects and hence rules out the problem of selectivity. In the regression I obviously control for the year in which the contract have been signed, in order to have a more comparable picture. The evidence shows that longer spells of non-employment in early period are statistically and negative correlated to wages, in line with other findings in the literature (Gregory and Jukes (2001); Gregg and Tominey (2005); Mroz and Savage (2006); Eliason and Storrie (2006)).

The third outcome considered is the probability to be overeducated in the last job. For graduate individuals, it is a dummy equal to 1 for individuals with job with no qualification or with low qualification, while for high school individuals it is equal to 1 for individuals with job with no qualification. Also in this case, it is necessary to keep in mind that there may be selection problem because of those who were not employed in Period 2 and consequently do not enter in the sample. In fact, people may choose to stay voluntarily unemployed if the available jobs do not match their level of qualification or do not satisfy their reservation wage. Results show a negative correlation between the early non-employment and the probability of being overeducated: the more the individual experienced early unemployment, the lower the probability to be overeducated. This may be explained by the positive returns to early job shopping, since in early periods workers learn about their skills and aptitudes 
by trying different jobs, leading to better matches as young workers move through a series of jobs. However, the coefficient is approximately equal to zero and the effect is negligible.

\section{Conclusions}

The available empirical evidence does not provide a unique answer on the existence of the scarring effects of early non-employment. I contribute to these studies by examining whether an individual's non-employment experience in the early career harms labour market outcomes in terms of future employment prospects, using Italian data. Moreover, I advance the theory on this topic by investigating the heterogeneous effects in different economic conditions and according to the individual characteristics.

The main methodological issue relates to the need to remove the bias that stems from unobserved factors that jointly influence both early and later non-employment. Specifically, rather than simply estimating least squares regressions, youth labor market conditions in the year before the one in which the individuals entered the work force are used as instrumental variables for the individual's experience of non-employment when young.

Understanding whether the effects of early-career non-employment are lasting or fade away after a while is crucial for justifying policies aimed at addressing schoolto-work transition and at preventing the incidence of youth unemployment. This has become a greater issue since the Great Recession, which had severely negative impacts mainly among younger individuals. To combat youth unemployment, many countries have implemented a wide range of policies. For example, Italy, like other European countries, committed to the Youth Guarantee Programme, to ensure that all young people under the age of 25 receive a good quality offer of employment within a period of four months of becoming unemployed or leaving formal education. Moreover, since 2015 the Italian Government has implemented the Programma Alternanza Scuola Lavoro in order to establish a first and direct connection between students and firms, which can be useful at the time of entry into the labour market, and introduced important fiscal incentives for hiring young people who have been unemployed for a long time.

My findings show that an increase in the duration of the non-employment spell increases the likelihood of suffering non-employment again in the future, confirming the state dependence in non-employment. The presence of a negative and causal relationships between past labour market experiences and later outcomes has serious implications from a policy point of view, since the the adverse effect of a past unemployment spell undermines the functioning of the labor market and leads to large social costs. Since personal characteristics (education, job qualifications) are relevant in influencing the size of the scarring effects, then policies should target these specific characteristics. The findings also show heterogeneity in the scarring effects with respect to labour market conditions: they are smaller if the individuals are unemployed in an area with high unemployment or during a period with increases in unemployment. In particular, the more widespread the status of unemployment, the less informative and 
scarring it is in order to detect the real worker's characteristics. Thus, the scarring effects are likely to be weaker during a severe recession than when it is experienced during a moderate recession.

These results are also important for shedding light on which prevailing mechanism underlies the scarring effects. The fact that the scarring effects are lower in regions with bad labour market conditions reveals the important of signalling theory in explaining the scarring effects.

To conclude, I points out some future lines of research that could be investigated. This work has an exclusive focus on the impact of early non-employment, but additional research could also be implemented in order to fully understand how early bad employment, and not only non-employment, affects labour market outcomes. For example, it could be interesting to evaluate the impact of early work experience in deskilling jobs or of job instability on later outcomes. The detrimental impact of these experiences could be just as important as the effect of having a history of non-employment and some evidence on that could be relevant for discussions concerning passive and active labour market policies. 


\section{References}

Acemoglu, D. (1995): "Public policy in a model of long-term unemployment," Economica, 161-178.

Altonji, J. G., L. B. Kahn, And J. D. Speer (2016): "Cashier or consultant? Entry labor market conditions, field of study, and career success," Journal of Labor Economics, 34, S361-S401.

Angrist, J. D. AND J.-S. PischKe (2008): Mostly harmless econometrics: An empiricist's companion, Princeton university press.

Arulampalam, W., A. L. Booth, and M. P. Taylor (2000): "Unemployment persistence," Oxford economic papers, 52, 24-50.

Ayllón, S. (2013): "Unemployment persistence: Not only stigma but discouragement too," Applied Economics Letters, 20, 67-71.

Biewen, M. And S. Steffes (2010): "Unemployment persistence: Is there evidence for stigma effects?" Economics Letters, 106, 188-190.

BRAndT, M. AND K. HANK (2014): "Scars that will not disappear: Long-term associations between early and later life unemployment under different welfare regimes," Journal of Social Policy, 43, 727-743.

Bugamelli, Matteo; Riccardo, C. And G. Zevi (2009): "International Crisis and the Italian Productive System: A Firm-Level Study," Tech. rep., Bank of Italy Occasional Paper 64.

Bun, M. J. AND T. D. HARRISON (2019): "OLS and IV estimation of regression models including endogenous interaction terms," Econometric Reviews, 38, 814-827.

Burgess, S., C. Propper, H. Rees, And A. Shearer (2003): "The class of 1981: the effects of early career unemployment on subsequent unemployment experiences," Labour Economics, 10, 291-309.

Caivano, Michele; Rodano, M. L. And S. Siviero (2010): "The Transmission of the Global Financial Crisis to the Italian Economy: A Counterfactual Analysis, 2008-2010." Tech. rep., Bank of Italy Occasional Paper 64.

Cockx, B. And C. Ghirelli (2016): "Scars of recessions in a rigid labor market," Labour Economics, 41, 162-176.

Cockx, B. And M. Picchio (2012): "Are short-lived jobs stepping stones to longlasting jobs?" Oxford Bulletin of Economics and Statistics, 74, 646-675. 
Corcoran, M. AND M. S. Hill (1985): "Reoccurrence of unemployment among adult men," Journal of Human Resources, 165-183.

Cornelissen, T., C. Dustmann, A. Raute, and U. Schönberg (2016): "From LATE to MTE: Alternative methods for the evaluation of policy interventions," Labour Economics, 41, 47-60.

Eliason, M. And D. Storrie (2006): "Lasting or latent scars? Swedish evidence on the long-term effects of job displacement," Journal of Labor Economics, 24, 831-856.

Ellwood, D. T. (1982): "Teenage unemployment: Permanent scars or temporary blemishes?" in The youth labor market problem: Its nature, causes, and consequences, University of Chicago Press, 349-390.

ERIKsson, S. And D.-O. Rooth (2014): "Do employers use unemployment as a sorting criterion when hiring? Evidence from a field experiment," American Economic Review, 104, 1014-39.

Farber, H. S., R. Hall, And J. Pencavel (1993): "The incidence and costs of job loss: 1982-91," Brookings papers on economic activity. Microeconomics, 1993, $73-132$.

Ghirelli, C. (2015): "Scars of early non-employment for low educated youth: evidence and policy lessons from Belgium," IZA Journal of European Labor Studies, 4, 20 .

Gibbons, R. And L. F. Katz (1991): "Layoffs and lemons," Journal of labor Economics, 9, 351-380.

GreGG, P. (2001): "The impact of youth unemployment on adult unemployment in the NCDS," The economic journal, 111, F626-F653.

GregG, P. And E. Tominey (2005): "The wage scar from male youth unemployment," Labour Economics, 12, 487-509.

Gregory, M. AND R. JukEs (2001): "Unemployment and subsequent earnings: Estimating scarring among British men 1984-94," The Economic Journal, 111, 607625.

HeCkman, J. J. (1979): "Sample selection bias as a specification error," Econometrica: Journal of the econometric society, 153-161.

Heckman, J. J. And G. J. BorJas (1980): "Does unemployment cause future unemployment? Definitions, questions and answers from a continuous time model of heterogeneity and state dependence," Economica, 47, 247-283. 
Imbens, G. W. And L. M. LynCH (2006): "Re-employment probabilities over the business cycle," Portuguese Economic Journal, 5, 111-134.

Imdorf, C., L. P. Shi, S. Sacchi, R. Samuel, C. Hyggen, R. Stoilova, G. Yordanova, P. Boyadjieva, P. Ilieva-Trichkova, D. Parsanoglou, ET AL. (2019): "Scars of early job insecurity across Europe: Insights from a multicountry employer study," Youth Unemployment and Job Insecurity in Europe. Problems, Risk Factors and Policies, 93-116.

Jacobson, L. S., R. J. LaLonde, And D. G. Sullivan (1993): "Earnings losses of displaced workers," The American economic review, 685-709.

KAHn, L. B. (2010): "The long-term labor market consequences of graduating from college in a bad economy," Labour Economics, 17, 303-316.

Kawaguchi, D. And T. Murao (2014): "Labor-Market Institutions and Long-Term Effects of Youth Unemployment," Journal of Money, Credit and Banking, 46, 95116.

Kroft, K., F. Lange, and M. J. Notowidigdo (2013): "Duration dependence and labor market conditions: Evidence from a field experiment," The Quarterly Journal of Economics, 128, 1123-1167.

Lockwood, B. (1991): "Information externalities in the labour market and the duration of unemployment," The Review of Economic Studies, 58, 733-753.

Lupi, C., P. Ordine, ET AL. (2002): "Unemployment scarring in high unemployment regions," Economics Bulletin, 10, 1-8.

Mooi-Reci, I. And H. B. Ganzeboom (2015): "Unemployment scarring by gender: Human capital depreciation or stigmatization? Longitudinal evidence from the Netherlands, 1980-2000," Social science research, 52, 642-658.

Mortensen, D. T. (1986): "Job search and labor market analysis," Handbook of labor economics, 2, 849-919.

Moulton, B. R. (1990): "An illustration of a pitfall in estimating the effects of aggregate variables on micro units," The review of Economics and Statistics, 334338 .

Mroz, T. A. And T. H. Savage (2006): "The long-term effects of youth unemployment," Journal of Human Resources, 41, 259-293.

Neumark, D. (2002): "Youth labor markets in the United States: Shopping around vs. staying put," Review of Economics and Statistics, 84, 462-482. 
Nilsen, Ø. A. AND K. H. Reiso (2011): "Scarring effects of unemployment," NHH Dept. of Economics Discussion Paper.

Nordstrom Skans, O. (2011): "Scarring effects of the first labor market experience,"

OMORI, Y. (1997): "Stigma effects of nonemployment," Economic Inquiry, 35, 394416.

Oreopoulos, P., T. Von Wachter, and A. Heisz (2012): "The short-and longterm career effects of graduating in a recession," American Economic Journal: Applied Economics, 4, 1-29.

Pastore, F. (2019): "Why so slow? The school-to-work transition in Italy," Studies in Higher Education, 44, 1358-1371.

Pissarides, C. A. (1992): "Loss of skill during unemployment and the persistence of employment shocks," The quarterly journal of economics, 107, 1371-1391.

RaAum, O. And K. Røed (2006): "Do business cycle conditions at the time of labor market entry affect future employment prospects?" The review of economics and statistics, 88, 193-210.

Russo, G., C. Gorter, and R. Schettkat (2001): "Searching, hiring and labour market conditions," Labour Economics, 8, 553-571.

Schmillen, A. And M. Umkehrer (2017): "The scars of youth: Effects of earlycareer unemployment on future unemployment experience," International Labour Review, 156, 465-494.

VishWANATH, T. (1989): "Job search, stigma effect, and escape rate from unemployment," Journal of Labor Economics, 7, 487-502.

Wooldridge, J. M. (2010): Econometric analysis of cross section and panel data, MIT press. 


\section{Tables}

Table 1: Descriptive statistics of the working sample.

\begin{tabular}{lccccc}
\hline \hline & Mean & SD & Min & Median & Max \\
\hline Days per year of non-employment in P2 & 195 & 128 & 0 & 208 & 365 \\
Days per year of non-employment in P1 & 291 & 98 & 0 & 344 & 365 \\
Sex & 0.52 & 0.49 & 0 & 1 & 1 \\
Age & 20.64 & 2.31 & 19 & 19 & 24 \\
Education & 1.34 & 0.47 & 1 & 1 & 2 \\
Entrance wage of the first job & 729 & 681 & 0 & 694 & 8,400 \\
Qualification of the first job & 1.96 & 0.83 & 1 & 2 & 3 \\
Moved to another region & 0.20 & 0.40 & 0 & 0 & 1 \\
Worked during school & 0.05 & 0.22 & 0 & 0 & 1 \\
Initial unemployment rate in P2 & 9.94 & 4.92 & 3.92 & 7.80 & 21.7 \\
Delta unempl. rate in P2 & -0.70 & 1.51 & -6.21 & -0.90 & 3.23 \\
Delta sectoral employment & -0.06 & 1.62 & -1.74 & 0.08 & 0.92 \\
\hline Total number of observations & 67,949 & & & & \\
\hline
\end{tabular}

Source: CICO and Regional Labour Force Survey.

Notes: sex is equal to 0 for male and equal to 1 for female; the age is computed at the beginning of Period 1, education is equal to 1 for individuals with high school diploma and equal to 2 for those with a degree; qualification is equal to 1 for low qualified workers, 2 for medium and 3 for high qualified workers; the variable Moved to another region is equal to 1 if the region of the first work is different from the region of birth. The initial unemployment rate and its variation in Period 2 are computed in the prevalent region of work and for the individuals with the same level of education. The delta sectoral employment is the variation in P2 in the number of employed individuals in the same region and sector of work and with the same level of education. 
Table 2: Days of non-employment per year in P2, by individual characteristics.

\begin{tabular}{lccccc}
\hline & $10 \%$ p. & Median & $90 \%$ p. & Mean & N(tot) \\
\hline Education & 2 & 230 & 364 & 209 & 44,700 \\
High school diploma & 0 & 167 & 350 & 169 & 23,249 \\
Degree & & & & & \\
\hline Prevalent sector of work & 23 & 252 & 363 & 226 & 1,592 \\
Agricolture and Fishery & 0 & 144 & 348 & 156 & 8,985 \\
Manifacturing & 0 & 195 & 365 & 188 & 2,336 \\
Construction & 0 & 186 & 349 & 127 & 11,567 \\
Wholesale and retail trade & 18 & 238 & 364 & 216 & 9,621 \\
Leisure and hospitality & 0 & 208 & 357 & 195 & 2,269 \\
Transport & 0 & 207 & 365 & 197 & 4,200 \\
Information and communication & 0 & 96 & 342 & 131 & 1,200 \\
Financial services & 3 & 229 & 364 & 209 & 10,156 \\
Real estate and business services & 0 & 208 & 355 & 191 & 962 \\
Public administration & 3 & 212 & 352 & 196 & 9,966 \\
Education and Health care & 25 & 264 & 365 & 230 & 5,098 \\
Other services & & & & &
\end{tabular}

Source: CICO. 
Table 3: Days of non-employment per year in P2, by regions and cohorts.

\begin{tabular}{lccccc}
\hline & $10 \%$ p. & Median & $90 \%$ p. & Mean & $\mathrm{N}$ (tot) \\
\hline Region of work & & & & & \\
Bolzano & 0 & 140 & 358 & 162 & 642 \\
Lombardia & 0 & 159 & 355 & 166 & 13,041 \\
Emilia Romagna & 0 & 164 & 352 & 169 & 4,179 \\
\hline Calabria & 39 & 273 & 365 & 242 & 2,111 \\
Sicilia & 46 & 271 & 365 & 239 & 4,960 \\
Molise & 41 & 253 & 363 & 225 & 341 \\
\hline Cohorts & & & & & \\
2009 & 0 & 196 & 358 & 186 & 33,857 \\
2010 & 6 & 218 & 363 & 204 & 34,092
\end{tabular}

Source: CICO.

I reported only the 3 regions with the lowest and the highest values of average days of non-employment per year in Period 2. 
Table 4: Correlation between early and late non employment

\begin{tabular}{lccccc}
\hline & $(1)$ & $(2)$ & $(3)$ & $(4)$ & $(5)$ \\
$\begin{array}{l}\text { Yearly average days of } \\
\text { non-emp. in P1 }\end{array}$ & $\begin{array}{c}\text { Number } \\
\text { of indiv. }\end{array}$ & $\begin{array}{c}\% \\
\text { of sample }\end{array}$ & $\begin{array}{c}\text { Yearly average days of } \\
\text { non-emp. in P2 }\end{array}$ & $\begin{array}{c}\text { P. of } \\
\text { non-empl. }\end{array}$ & $\begin{array}{c}\text { N. of } \\
\text { contracts }\end{array}$ \\
\hline 0 days & 409 & 0.6 & 78.6 & 16.8 & 1.66 \\
1-90 days & 3,639 & 5.3 & 108.1 & 24.3 & 1.88 \\
91-180 days & 7,021 & 10.3 & 121.3 & 27.6 & 1.94 \\
181-270 days & 10,010 & 14.7 & 152.5 & 35.2 & 2.55 \\
271-364 days & 18,861 & 27.7 & 210.1 & 47.6 & 3.14 \\
365 days & 28,009 & 41.2 & 233.5 & 39.1 & 2.38
\end{tabular}

Source: CICO data. The III column reports the number of days in which the individual is not employed in Period 2, the fourth column reports the percentage of individuals that are non-employed at the end of Period 2, while the last column reports the number of contracts in Period 2. 
Table 5: Main results.

\begin{tabular}{|c|c|c|c|c|}
\hline \multicolumn{5}{|c|}{ Average yearly days spent in non-emp. in P2 } \\
\hline & $(1)$ & $(2)$ & $(3)$ & $(4)$ \\
\hline & OLS & TOBIT & IVREG & IVTOBIT \\
\hline \multirow[t]{2}{*}{ Yearly days in non-emp. in P1 } & $0.44^{* * *}$ & $0.55^{* * *}$ & $1.03^{* * *}$ & $1.01^{* * *}$ \\
\hline & $(0.02)$ & $(0.02)$ & $(0.16)$ & $(0.06)$ \\
\hline \multicolumn{5}{|l|}{ First stage } \\
\hline \multirow[t]{2}{*}{ Youth unemp. rate $_{t_{0} r d}$} & & & $0.74^{* * *}$ & $0.77^{* * *}$ \\
\hline & & & $(0.07)$ & $(0.09)$ \\
\hline F stat. & & & 115.98 & \\
\hline Prob $>$ F & & & $(0.00)$ & \\
\hline N. obs. & 67,949 & 67,949 & 67,949 & 67,949 \\
\hline $\mathrm{R}$ squared/Uncentered $\mathrm{R}$ squared & 0.19 & & 0.70 & \\
\hline
\end{tabular}

Source: CICO and Regional Labour Force Survey.

Notes: All the regressions include individual characteristics (sex, age squared, entrance wage of the first job, qualification of the first job, a dummy equal to 1 if the region of birth is different from the region of the first work, a dummy equal to 1 if the individual starts to work before the end of the school, level of education, prevalent sector of work in Period 1), dummies for the region of work, the cohort and for the interactions between the region of work and the cohort. Controls for the economic conditions in period 2 are the initial unemployment rate in the region of work for people with the same level of education, the variation in this unemployment rate and the variation of the employed individuals in the same sector, region and with the same level of education.

Standard errors are clustered according to the region of birth, the cohort and the educational level. Standard errors in parentheses. ${ }^{*} \mathrm{p}<0.10,{ }^{* *} \mathrm{p}<0.05,{ }^{* * *} \mathrm{p}<0.01$. 
Table 6: Full regressions.

\begin{tabular}{lcccc}
\hline \hline & OLS & TOBIT & IVREG & IVTOBIT \\
\hline Early non emp. & $0.44^{* * *}$ & $0.55^{* * *}$ & $1.03^{* * *}$ & $1.01^{* * *}$ \\
& $(0.02)$ & $(0.02)$ & $(0.16)$ & $(0.06)$ \\
Male & 0.36 & 0.11 & $2.06^{* * *}$ & 1.46 \\
& $(0.99)$ & $(1.57)$ & $(1.11)$ & $(1.13)$ \\
Age squared & $0.08^{* * *}$ & $0.099^{* * *}$ & $0.13^{* * *}$ & $0.13^{* * *}$ \\
& $(0.03)$ & $(0.04)$ & $(0.04)$ & $(0.04)$ \\
Initial wage & $-0.002^{* *}$ & $-0.005^{* *}$ & $-0.005^{* *}$ & $-0.007^{* *}$ \\
& $(0.0008)$ & $(0.0009)$ & $(0.001)$ & $(0.001)$ \\
Moved to another reg. & $14.4^{* * *}$ & $16.2^{* *}$ & 2.58 & $6.955^{* *}$ \\
& $(1.49)$ & $(1.74)$ & $(3.16)$ & $(2.13)$ \\
Work during school & $43.9^{* * *}$ & $55.7^{* * *}$ & $137.8^{* * *}$ & $129.30^{* *}$ \\
& $(3.38)$ & $(4.4)$ & $(25.88)$ & $(10.22)$ \\
High school diploma & $42.04^{* * *}$ & $48.4^{* * *}$ & $50.18^{* * *}$ & $54.7^{* * *}$ \\
& $(6.58)$ & $(8.46)$ & $(7.9)$ & $(8.69)$ \\
Low qualification & $10.4^{* * * *}$ & $11.5^{* * *}$ & $6.95^{* * *}$ & $9.78^{* * *}$ \\
\multirow{2}{*}{ Medium qualification } & $(1.23)$ & $(2.18)$ & $(1.89)$ & $(2.13)$ \\
& -1.2 & -1.04 & -1.8 & -1.5 \\
& $(1.8)$ & $(2.18)$ & $(1.7)$ & $(2.07)$ \\
\hline N tot & 67,949 & 67,949 & 67,949 & 67,949 \\
\hline
\end{tabular}

Source: CICO data and Regional Labour Force Survey.

Note: Omitted categories are: female, degree and high qualification. All the regressions also include dummies for the prevalent sector of work in Period 1, the region of work, the cohort and the interactions between the region of work and the cohort. Controls for the economic conditions in period 2 are the initial unemployment rate in the region of work for people with the same level of education, the variation in this unemployment rate and the variation of the employed individuals in the same sector, region and with the same level of education. Standard errors in parentheses. ${ }^{*} \mathrm{p}<0.10,{ }^{* *} \mathrm{p}<0.05$, $* * * \mathrm{p}<0.01$. 
Table 7: IV results by individual characteristics.

\begin{tabular}{lcccccc}
\hline \hline \multicolumn{7}{c}{ Average yearly days spent in non-emp. in P2 } \\
\hline & $(1)$ & $(2)$ & $(3)$ & $(4)$ & $(5)$ & $(6)$ \\
& Male & Female & High school & Degree & Low/medium & High \\
\hline Non-emp. in P1 & $0.92^{* * *}$ & $1.10^{* * *}$ & $1.28^{* * *}$ & $0.76^{* * *}$ & $1.19^{* * *}$ & $0.86^{* * *}$ \\
& $(0.21)$ & $(0.18)$ & $(0.21)$ & $(0.18)$ & $(0.19)$ & $(0.22)$ \\
\hline \multicolumn{7}{c}{ First stage } \\
\hline Youth unemp. rate $t_{0} r d$ & $0.64^{* * *}$ & $0.83^{* * *}$ & $0.67^{* * *}$ & $1.16^{* * *}$ & $0.68^{* * *}$ & $0.90^{* * *}$ \\
& $(0.09)$ & $(0.09)$ & $(0.07)$ & $(0.17)$ & $(0.07)$ & $(0.12)$ \\
F stat. & 46.60 & 72.41 & 97.88 & 43.45 & 79.36 & 56.98 \\
Prob $>$ F & $(0.00)$ & $(0.00)$ & $(0.00)$ & $(0.00)$ & $(0.00)$ & $(0.00)$ \\
\hline N. obs. & 31,945 & 36,004 & 44,739 & 23,210 & 47,534 & 20,415 \\
\hline
\end{tabular}

Source: CICO and Regional Labour Force Survey.

Notes: Low, medium and high identify the individual job qualification of the individual in Period 2. All the regressions include individual characteristics (sex, age squared, entrance wage of the first job, qualification of the first job, a dummy equal to 1 if the region of birth is different from the region of the first work, a dummy equal to 1 if the individual starts to work before the end of the school, level of education, prevalent sector of work in Period 1), dummies for the region of work, the cohort and for the interactions between the region of work and the cohort. Controls for the economic conditions in period 2 are the initial unemployment rate, the variation in the unemployment rate and the variation of the employed individuals in the same sector.

Standard errors, in parentheses, are clustered according to the region of birth, the cohort and the educational level. ${ }^{*} \mathrm{p}<0.10,{ }^{* *} \mathrm{p}<0.05,{ }^{* * *} \mathrm{p}<0.01$. 
Table 8: IV results by area and labour market characteristics.

\begin{tabular}{|c|c|c|c|c|}
\hline \multicolumn{5}{|c|}{ Average yearly days spent in non-emp. in P2 } \\
\hline & $(1)$ & $(2)$ & $(3)$ & $(4)$ \\
\hline & $\begin{array}{l}\text { Cond.1 } \\
\text { in P2 }\end{array}$ & $\begin{array}{l}\text { Cond.2 } \\
\text { in P2 }\end{array}$ & $\begin{array}{l}\text { Cond.1 } \\
\text { in P1 }\end{array}$ & $\begin{array}{l}\text { Cond.2 } \\
\text { in P1 }\end{array}$ \\
\hline Non-emp. in P1 & $\begin{array}{c}1.41^{* * *} \\
(0.24)\end{array}$ & $\begin{array}{c}0.80 * * * \\
(0.22)\end{array}$ & $\begin{array}{c}1.12^{* * *} \\
(0.21)\end{array}$ & $\begin{array}{c}1.02^{* * *} \\
(0.16)\end{array}$ \\
\hline Interaction & $\begin{array}{l}-0.06^{*} \\
(0.04)\end{array}$ & $\begin{array}{c}-0.15^{* *} \\
(0.08)\end{array}$ & $\begin{array}{c}-0.0049 \\
(0.07)\end{array}$ & $\begin{array}{c}0.075 \\
(0.45)\end{array}$ \\
\hline Cond.1 & $\begin{array}{l}23.3^{*} \\
(14.8)\end{array}$ & & $\begin{array}{c}15.49 \\
(21.35)\end{array}$ & \\
\hline Cond.2 & & $\begin{array}{c}45.2^{* * *} \\
(23.6)\end{array}$ & & $\begin{array}{l}-22.5 \\
(13.4) \\
\end{array}$ \\
\hline \multicolumn{5}{|c|}{ First stage - Non-emp. in P1 } \\
\hline Youth unemp. rate $_{t_{0} r d}$ & $\begin{array}{c}1.38 * * * \\
(0.15)\end{array}$ & $\begin{array}{c}0.69 * * * \\
(0.07)\end{array}$ & $\begin{array}{c}1.46^{* * *} \\
(0.14)\end{array}$ & $\begin{array}{c}0,77^{* * *} \\
(0,07)\end{array}$ \\
\hline Youth unemp. rate $_{t_{0} r d} *$ Cond & $\begin{array}{c}-0.07^{* * *} \\
(0.01)\end{array}$ & $\begin{array}{c}-0.05^{*} \\
(0.04)\end{array}$ & $\begin{array}{c}-0.11^{* * *} \\
(0.21)\end{array}$ & $\begin{array}{l}-0,05 \\
(0.03)\end{array}$ \\
\hline F stat. & 64.6 & 59.06 & 64.97 & 57.87 \\
\hline Prob $>$ F & $(0.00)$ & $(0.00)$ & $(0.00)$ & $(0.00)$ \\
\hline \multicolumn{5}{|c|}{ First stage -Interaction term } \\
\hline Youth unemp. rate $_{t_{0} r d}$ & $\begin{array}{c}2.4^{*} \\
(1.5)\end{array}$ & $\begin{array}{c}-0.51^{* *} \\
(0.24)\end{array}$ & $\begin{array}{l}1.45^{*} \\
(0.99)\end{array}$ & $\begin{array}{c}-0,83^{* * *} \\
(0.21)\end{array}$ \\
\hline Youth unemp. rate $_{t_{0} r d} *$ Cond & $\begin{array}{l}0.21^{*} \\
(0.17)\end{array}$ & $\begin{array}{c}0.70^{* * *} \\
(0.16)\end{array}$ & $\begin{array}{c}0.09 \\
(0.15)\end{array}$ & $\begin{array}{c}1.2 \\
(0.17)\end{array}$ \\
\hline F stat. & 22.1 & 36.3 & 7.84 & 22.74 \\
\hline Prob $>\mathrm{F}$ & $(0.00)$ & $(0.00)$ & $(0.00)$ & $(0.00)$ \\
\hline \multicolumn{5}{|c|}{ Kleibergen-Paap Wald F statistic } \\
\hline Statistic & 8.96 & 6.82 & 2.99 & 41.58 \\
\hline $10 \%$ critical values & 7.03 & 7.03 & 7.03 & 7.0 \\
\hline N. obs. & 67,949 & 67,949 & 67,949 & 67,949 \\
\hline
\end{tabular}

Source: CICO and Regional Labour Force Survey.

Notes: I display the results of the regressions when I include the interaction terms between the individual early non-employment and the labour market condition (Cond1 and Cond2). Cond1 is the unemployment rate in the region of work for individuals with education $\mathrm{d}$ measured at the beginning of Period 2 (Period 1 in the III column), Cond2 is the change in the unemployment rate in the region of work for individuals with education d during Period 2 (Period 1 in the IV column). All the regressions include individual characteristics (sex, age squared, entrance wage of the first job, qualification of the first job, a dummy equal to 1 if the region of birth is different from the region of the first work, a dummy equal to 1 if the individual starts to work before the end of the school, level of education, prevalent sector of work in Period 1), dummies for the region of work, the cohort and for the interactions between the region of work and the cohort. Standard errors, in parentheses, are clustered according to the region of birth, the cohort and the educational level. ${ }^{*} \mathrm{p}<0.10,{ }^{* *} \mathrm{p}<0.05$, $* * * \mathrm{p}<0.01$. 
Table 9: Different instruments and sample

\begin{tabular}{|c|c|c|c|c|}
\hline \multicolumn{5}{|c|}{ Average yearly days spent in non-emp. in P2 } \\
\hline & $(\mathrm{I})$ & (II) & (III) & (IV). \\
\hline & Area & Reg. & Restr. & Restr. \\
\hline & of birth & of work & sample & sample \\
\hline & IVREG & IVREG & OLS & IVREG \\
\hline Yearly days in non-emp. in P1 & $0.92 * * *$ & $1.34^{* * *}$ & $0.40^{* * *}$ & $0.88 * * *$ \\
\hline & $(0.23)$ & $(0.32)$ & $(0.02)$ & $(0.25)$ \\
\hline \multicolumn{5}{|c|}{ First stage } \\
\hline Youth unemp. rate $_{t_{0} r d}$ & $1.14^{* * *}$ & $0.69 * * *$ & & $0.64^{* * *}$ \\
\hline & $(0.20)$ & $(0.16)$ & & $(0.09)$ \\
\hline F stat. & 31.81 & 17.15 & & 43.35 \\
\hline Prob $>$ F & $(0.00)$ & $(0.00)$ & & $(0.00)$ \\
\hline N. obs. & 67,949 & 67,949 & 40,730 & 40,730 \\
\hline $\mathrm{R}$ squared/Uncentered R squared & 0.73 & 0.91 & 0.18 & 0.64 \\
\hline
\end{tabular}

Source: CICO and RFL data.

Notes: All the regressions include the same controls as in the baseline specification. In column I, I use as instrument the unemployment rate in the area of birth; in column II the regional unemployment rate in the region of work. Standard errors are clustered at the same level of the instrument. Columns III and IV reports the results obtained using the restricted samples of observations. Standard errors in parentheses. ${ }^{*} \mathrm{p}<0.10,{ }^{* *} \mathrm{p}<0.05,{ }^{* * *} \mathrm{p}<0.01$. 
Table 10: IV results on different outcomes.

\begin{tabular}{lccc}
\hline & Job instability & Wage & Overeducation \\
\hline Yearly days in non-emp. in P1 & $0.03^{* * *}$ & $-5.45^{* * *}$ & $-0.001^{* * *}$ \\
& $(0.006)$ & $(1.80)$ & $(0.0003)$ \\
\hline & First stage & & \\
\hline Youth unemp. rate $_{t_{0} r d}$ & $0.74^{* * *}$ & $0.49^{* * *}$ & $0.76^{* * *}$ \\
& $(0.07)$ & $(0.06)$ & $(0.07)$ \\
F stat. & 115.98 & 67.26 & 115.85 \\
Prob $>$ F & $(0.00)$ & $(0.00)$ & $(0.00)$ \\
\hline N. obs. & 67,949 & 67,949 & 63,054 \\
\hline
\end{tabular}

Source: CICO and RFL data.

Notes: Job instability is measured as the number of contract that ended in Period 2, the wage is the initial wage of the last contract signed in Period 2, Overeducation is a dummy equal to 1 is the individual is overeducated in the last contract signed in Period 2. All the regressions include individual characteristics (sex, age squared, entrance wage of the first job, qualification of the first job, a dummy equal to 1 if the region of birth is different from the region of the first work, a dummy equal to 1 if the individual starts to work before the end of the school, level of education, prevalent sector of work in Period 1), dummies for the region of work, the cohort and for the interactions between the region of work and the cohort. Controls for the economic conditions in period 2 are the initial unemployment rate, the variation in the unemployment rate and the variation of the employed individuals in the same sector. The wage regression also includes, as control, a variable that reports the year in which the contract has been signed. Standard errors (in parentheses) are clustered according to the region of birth, the cohort and the educational level. ${ }^{*} \mathrm{p}<0.10,{ }^{* *} \mathrm{p}<0.05,{ }^{* * *} \mathrm{p}<0.01$. 


\section{RECENTLY PUBLISHED “TEMI” (*)}

N.1287 - Court efficiency and aggregate productivity: the credit channel, by Guzmán González-Torres and Giacomo Rodano (July 2020).

N. 1288 - The time-varying risk of Italian GDP, by Fabio Busetti, Michele Caivano, Davide Delle Monache and Claudia Pacella (July 2020).

N.1289 - Trade shocks and credit reallocation, by Stefano Federico, Fadi Hassan and Veronica Rappoport (July 2020).

N. 1290 - The impact of the IRB approach on the relationship between the cost of credit for public companies and financial market conditions, by Raffaele Gallo (July 2020).

N. 1291 - An economic assessment of the evolution of the corporate tax system in Italy, by Ernesto Zangari (September 2020).

N.1292 - Asymmetric information in corporate lending: evidence from SME bond markets, by Alessandra Iannamorelli, Stefano Nobili, Antonio Scalia and Luana Zaccaria (September 2020).

N. 1293 - Fiscal space and the size of fiscal multiplier, by Luca Metelli and Kevin Pallara (September 2020).

N.1294 - Prudential policies, credit supply and house prices: evidence from Italy, by Pierluigi Bologna, Wanda Cornacchia and Maddalena Galardo (September 2020).

N. 1295 - How loose, how tight? A measure of monetary and fiscal stance for the euro area, by Nicoletta Batini, Alessandro Cantelmo, Giovanni Melina and Stefania Villa (September 2020).

N. 1296 - Price dividend ratio and long-run stock returns: a score driven state space model, by Davide Delle Monache, Ivan Petrella and Fabrizio Venditti (September 2020).

N.1297 - Workforce aging, pension reforms, and firm outcomes, by Francesca Carta, Francesco D'Amuri and Till von Wachter (September 2020).

N. 1298 - Anti-poverty measures in Italy: a microsimulation analysis, by Nicola Curci, Giuseppe Grasso, Pasquale Recchia and Marco Savegnago (September 2020).

N. 1299 - Forecasting US recessions: the role of economic uncertainty, by Valerio Ercolani and Filippo Natoli (September 2020).

N.1300 - Demographics and the natural real interest rate: historical and projected paths for the euro area, by Andrea Papetti (November 2020).

N.1301 - A quantitative analysis of distortions in managerial forecasts, by Yueran Ma, Tiziano Ropele, David Sraer and David Thesmar (November 2020).

N. 1302 - Bargaining power and the Phillips curve: a micro-macro analysis, by Marco J. Lombardi, Marianna Riggi and Eliana Viviano (November 2020).

N. 1303 - The effects of structural reforms: Evidence from Italy, by Emanuela Ciapanna, Sauro Mocetti and Alessandro Notarpietro (November 2020).

N. 1304 - Consumption and Wealth: New Evidence from Italy, by Riccardo De Bonis, Danilo Liberati, John Muellbauer and Concetta Rondinelli (November 2020).

N. 1305 - Do details matter? An analysis of the Italian personal income tax, by Martino Tasso (November 2020).

N. 1306 - Effects of eligibility for central bank purchases on corporate bond spreads, by Taneli Mäkinen, Fan Li, Andrea Mercatanti and Andrea Silvestrini (November 2020).

(*) Requests for copies should be sent to:

Banca d'Italia - Servizio Studi di struttura economica e finanziaria - Divisione Biblioteca e Archivio storico - Via Nazionale, 91 - 00184 Rome - (fax 003906 47922059). They are available on the Internet www.bancaditalia.it. 
Accetturo A., V. Di Giacinto, G. Micucci and M. Pagnini, Geography, productivity and trade: does selection explain why some locations are more productive than others?, Journal of Regional Science, v. 58, 5, pp. 949-979, WP 910 (April 2013).

ADAMOPOULOU A. and E. KAYA, Young adults living with their parents and the influence of peers, Oxford Bulletin of Economics and Statistics,v. 80, pp. 689-713, WP 1038 (November 2015).

Andini M., E. Ciani, G. De Blasio, A. D’Ignazio and V. Silvestrini, Targeting with machine learning: an application to a tax rebate program in Italy, Journal of Economic Behavior \& Organization, v. 156, pp. 86-102, WP 1158 (December 2017).

BARONE G., G. DE BLASIO and S. MOCETTI, The real effects of credit crunch in the great recession: evidence from Italian provinces, Regional Science and Urban Economics, v. 70, pp. 352-59, WP 1057 (March 2016).

Belotti F. and G. IlARDi Consistent inference in fixed-effects stochastic frontier models, Journal of Econometrics, v. 202, 2, pp. 161-177, WP 1147 (October 2017).

Berton F., S. Mocetti, A. Presbitero and M. Richiardi, Banks, firms, and jobs, Review of Financial Studies, v.31, 6, pp. 2113-2156, WP 1097 (February 2017).

Bofondi M., L. CARPinelli and E. SETte, Credit supply during a sovereign debt crisis, Journal of the European Economic Association, v.16, 3, pp. 696-729, WP 909 (April 2013).

Bokan N., A. Gerali, S. Gomes, P. JACQuinOt and M. PiSANI, EAGLE-FLI: a macroeconomic model of banking and financial interdependence in the euro area, Economic Modelling, v. 69, C, pp. 249280, WP 1064 (April 2016).

BRILli Y. and M. TONELlo, Does increasing compulsory education reduce or displace adolescent crime? New evidence from administrative and victimization data, CESifo Economic Studies, v. 64, 1, pp. 15-4, WP 1008 (April 2015).

BUONO I. and S. FORMAI The heterogeneous response of domestic sales and exports to bank credit shocks, Journal of International Economics, v. 113, pp. 55-73, WP 1066 (March 2018).

Burlon L., A. Gerali, A. NotarPietro and M. Pisani, Non-standard monetary policy, asset prices and macroprudential policy in a monetary union, Journal of International Money and Finance, v. 88, pp. 25-53, WP 1089 (October 2016).

CARTA F. and M. DE PHLIPPIS, You've Come a long way, baby. Husbands' commuting time and family labour supply, Regional Science and Urban Economics, v. 69, pp. 25-37, WP 1003 (March 2015).

CARTA F. and L. RIZZICA, Early kindergarten, maternal labor supply and children's outcomes: evidence from Italy, Journal of Public Economics, v. 158, pp. 79-102, WP 1030 (October 2015).

Casiraghi M., E. Gaiotti, L. Rodano and A. SECchi, A “Reverse Robin Hood"? The distributional implications of non-standard monetary policy for Italian households, Journal of International Money and Finance, v. 85, pp. 215-235, WP 1077 (July 2016).

CIANI E. and C. DEIANA, No Free lunch, buddy: housing transfers and informal care later in life, Review of Economics of the Household, v.16, 4, pp. 971-1001, WP 1117 (June 2017).

Cipriani M., A. Guarino, G. Guazzarotti, F. Tagliati and S. Fisher, Informational contagion in the laboratory, Review of Finance, v. 22, 3, pp. 877-904, WP 1063 (April 2016).

De Blasio G, S. De Mitri, S. D’Ignazio, P. Finaldi Russo and L. Stoppani, Public guarantees to SME borrowing. A RDD evaluation, Journal of Banking \& Finance, v. 96, pp. 73-86, WP 1111 (April 2017).

Gerali A., A. LocARno, A. NotARPIETRO and M. PISANI, The sovereign crisis and Italy's potential output, Journal of Policy Modeling, v. 40, 2, pp. 418-433, WP 1010 (June 2015).

LIBERATI D., An estimated DSGE model with search and matching frictions in the credit market, International Journal of Monetary Economics and Finance (IJMEF), v. 11, 6, pp. 567-617, WP 986 (November 2014).

LinAREllo A., Direct and indirect effects of trade liberalization: evidence from Chile, Journal of Development Economics, v. 134, pp. 160-175, WP 994 (December 2014).

NAtoli F. and L. SigAlotTi, Tail co-movement in inflation expectations as an indicator of anchoring, International Journal of Central Banking, v. 14, 1, pp. 35-71, WP 1025 (July 2015).

NuCCI F. and M. RigGI, Labor force participation, wage rigidities, and inflation, Journal of Macroeconomics, v. 55, 3 pp. 274-292, WP 1054 (March 2016).

RIGON M. and F. ZANETTI, Optimal monetary policy and fiscal policy interaction in a non_ricardian economy, International Journal of Central Banking, v. 14 3, pp. 389-436, WP 1155 (December 2017). 
SEGURA A., Why did sponsor banks rescue their SIVs?, Review of Finance, v. 22, 2, pp. 661-697, WP 1100 (February 2017).

AlbANESE G., M. CIOFFI and P. TOMMASINO, Legislators' behaviour and electoral rules: evidence from an Italian reform, European Journal of Political Economy, v. 59, pp. 423-444, WP 1135 (September 2017).

Aprigliano V., G. ArdizzI and L. MonTEForte, Using the payment system data to forecast the economic activity, International Journal of Central Banking, v. 15, 4, pp. 55-80, WP 1098 (February 2017).

ARNAUdo D., G. MiCUCCI, M. RigON and P. Rossi, Should I stay or should I go? Firms' mobility across banks in the aftermath of the financial crisis, Italian Economic Journal / Rivista italiana degli economisti, v. 5, 1, pp. 17-37, WP 1086 (October 2016).

BASSO G., F. D’AMURI and G. PERI, Immigrants, labor market dynamics and adjustment to shocks in the euro area, IMF Economic Review, v. 67, 3, pp. 528-572, WP 1195 (November 2018).

BAtini N., G. MelinA and S. Villa, Fiscal buffers, private debt, and recession: the good, the bad and the ugly, Journal of Macroeconomics, v. 62, WP 1186 (July 2018).

Burlon L., A. Notarpietro and M. Pisani, Macroeconomic effects of an open-ended asset purchase programme, Journal of Policy Modeling, v. 41, 6, pp. 1144-1159, WP 1185 (July 2018).

Busetti F. and M. CAIVANO, Low frequency drivers of the real interest rate: empirical evidence for advanced economies, International Finance, v. 22, 2, pp. 171-185, WP 1132 (September 2017).

CAppelletti G., G. GuAzZAROtTi and P. TOMmasino, Tax deferral and mutual fund inflows: evidence from a quasi-natural experiment, Fiscal Studies, v. 40, 2, pp. 211-237, WP 938 (November 2013).

CARDANi R., A. PACCAGNINI and S. VILla, Forecasting with instabilities: an application to DSGE models with financial frictions, Journal of Macroeconomics, v. 61, WP 1234 (September 2019).

Chiades P., L. Greco, V. Mengotto, L. Moretti and P. Valbonesi, Fiscal consolidation by intergovernmental transfers cuts? The unpleasant effect on expenditure arrears, Economic Modelling, v. 77, pp. 266-275, WP 1076 (July 2016).

CIANI E., F. DAVID and G. DE BLASIO, Local responses to labor demand shocks: a re-assessment of the case of Italy, Regional Science and Urban Economics, v. 75, pp. 1-21, WP 1112 (April 2017).

CIANI E. and P. FISHER, Dif-in-dif estimators of multiplicative treatment effects, Journal of Econometric Methods, v. 8. 1, pp. 1-10, WP 985 (November 2014).

CIAPANNA E. and M. TABOGA, Bayesian analysis of coefficient instability in dynamic regressions, Econometrics, MDPI, Open Access Journal, v. 7, 3, pp.1-32, WP 836 (November 2011).

Coletta M., R. De Bonis and S. PIERMATteI, Household debt in OECD countries: the role of supply-side and demand-side factors, Social Indicators Research, v. 143, 3, pp. 1185-1217, WP 989 (November 2014).

Cova P., P. PAgAno and M. PISAni, Domestic and international effects of the Eurosystem Expanded Asset Purchase Programme, IMF Economic Review, v. 67, 2, pp. 315-348, WP 1036 (October 2015).

ERColani V. and J. VAlle E AzEVEDo, How can the government spending multiplier be small at the zero lower bound?, Macroeconomic Dynamics, v. 23, 8. pp. 3457-2482, WP 1174 (April 2018).

FERrero G., M. Gross and S. NerI, On secular stagnation and low interest rates: demography matters, International Finance, v. 22, 3, pp. 262-278, WP 1137 (September 2017).

FoA G., L. Gambacorta, L. Guiso and P. E. Mistrulli, The supply side of household finance, Review of Financial Studies, v.32, 10, pp. 3762-3798, WP 1044 (November 2015).

Giordano C., M. MARINUCCI and A. Silvestrini, The macro determinants of firms' and households' investment: evidence from Italy, Economic Modelling, v. 78, pp. 118-133, WP 1167 (March 2018).

Gomellini M., D. Pellegrino and F. GifFoni, Human capital and urban growth in Italy,1981-2001, Review of Urban \& Regional Development Studies, v. 31, 2, pp. 77-101, WP 1127 (July 2017).

MAGRI S., Are lenders using risk-based pricing in the Italian consumer loan market? The effect of the 2008 crisis, Journal of Credit Risk, v. 15, 1, pp. 27-65, WP 1164 (January 2018).

MercatANTi A., T. MAKINEN and A. SiLVESTRINI, The role of financial factors for european corporate investment, Journal of International Money and Finance, v. 96, pp. 246-258, WP 1148 (October 2017).

Miglietta A., C. Picillo and M. Pietrunt, The impact of margin policies on the Italian repo market, The North American Journal of Economics and Finance, v. 50, WP 1028 (October 2015). 
MONTEFORTE L. and V. RAPONI, Short-term forecasts of economic activity: are fortnightly factors useful?, Journal of Forecasting, v. 38, 3, pp. 207-221, WP 1177 (June 2018).

Neri S. and A. NOTARPIETRO, Collateral constraints, the zero lower bound, and the debt-deflation mechanism, Economics Letters, v. 174, pp. 144-148, WP 1040 (November 2015).

PANCRAZI R. and M. PIETRUNTI, Natural expectations and home equity extraction, Journal of Housing Economics , v. 46, 4, WP 984 (November 2014).

PEREDA FERnANDEZ S., Teachers and cheaters. Just an anagram?, Journal of Human Capital, v. 13, 4, pp. 635-669, WP 1047 (January 2016).

RigGi M., Capital destruction, jobless recoveries, and the discipline device role of unemployment, Macroeconomic Dynamics, v. 23, 2, pp. 590-624, WP 871 (July 2012).

2020

Alessandri P. and M. Bottero, Bank lending in uncertain times, R European Economic Review, V. 128, WP 1109 (April 2017).

Antunes A. and V. Ercolani, Public debt expansions and the dynamics of the household borrowing constraint, Review of Economic Dynamics, v. 37, pp. 1-32, WP 1268 (March 2020).

ARDUINI T., E. PATACCHINI and E. RAINONE, Treatment effects with heterogeneous externalities, Journal of Business \& Economic Statistics, , v. 38, 4, pp. 826-838, WP 974 (October 2014).

BRIPI F., D. LOSCHIAVO and D. REVELLI, Services trade and credit frictions: evidence with matched bankfirm data, The World Economy, v. 43, 5, pp. 1216-1252, WP 1110 (April 2017).

BRONZINI R., G. CARAMELLINO and S. MAGRI, Venture capitalists at work: a Diff-in-Diff approach at latestages of the screening process, Journal of Business Venturing, v. 35, 3, WP 1131 (September 2017).

COIBION O., Y. GORODNICHENKO and T. ROPELE, Inflation expectations and firms' decisions: new causal evidence, Quarterly Journal of Economics, v. 135, 1, pp. 165-219, WP 1219 (April 2019).

CORSELlO F. and V. NISPI LANDI, Labor market and financial shocks: a time-varying analysis, Journal of Money, Credit and Banking, v. 52, 4, pp. 777-801, WP 1179 (June 2018).

COVA P. and F. NATOLI, The risk-taking channel of international financial flows, Journal of International Money and Finance, v. 102, WP 1152 (December 2017).

D'IGNAZIO A. and C. MENON, The causal effect of credit Guarantees for SMEs: evidence from Italy, The Scandinavian Journal of Economics, v. 122, 1, pp. 191-218, WP 900 (February 2013).

ERCOLANi V. and F. NATOLI, Forecasting US recessions: the role of economic uncertainty, Economics Letters, v. 193, WP 1299 (October 2020).

MAKINEN T., L. SARNO and G. ZINNA, Risky bank guarantees, Journal of Financial Economics, v. 136, 2, pp. 490522, WP 1232 (July 2019).

NisPi LANDI V., Capital controls spillovers, Journal of International Money and Finance, v. 109, WP 1184 (July 2018).

RAINONE E. and F. VACIRCA, Estimating the money market microstructure with negative and zero interest rates, Quantitative Finance, v. 20, 2, pp. 207-234, WP 1059 (March 2016).

RIZZICA L., Raising aspirations and higher education. Evidence from the UK's widening participation policy, Journal of Labor Economics, v. 38, 1, pp. 183-214, WP 1188 (September 2018).

SANTIONI, R., F. SCHIANTARELLI and P. STRAHAN, Internal capital markets in times of crisis: the benefit of group affiliation, Review of Finance, v. 24, 4, pp. 773-811, WP 1146 (October 2017).

SChiantarelli F., M. Stacchini and P. Strahan, Bank Quality, judicial efficiency and loan repayment delays in Italy, Journal of Finance, v. 75, 4, pp. 2139-2178, WP 1072 (July 2016).

\section{FORTHCOMING}

Albanese G., G. DE Blasio and A. LocAtelli, Does EU regional policy promote local TFP growth? Evidence from the Italian Mezzogiorno, Papers in Regional Science, WP 1253 (December 2019).

Baltrunaite A., C. Giorgiantonio, S. Mocetti and T. Orlando, Discretion and supplier selection in public procurement, Journal of Law, Economics, and Organization, WP 1178 (June 2018). 
Bologna P., A. Miglietta and A. Segura, Contagion in the CoCos market? A case study of two stress events, International Journal of Central Banking, WP 1201 (November 2018).

BotTERo M., F. MEZZANOTTI and S. LENZU, Sovereign debt exposure and the Bank Lending Channel: impact on credit supply and the real economy, Journal of International Economics, WP 1032 (October 2015).

BRONZINI R., S. MOCETTI and M. MONGARDINI, The economic effects of big events: evidence from the Great Jubilee 2000 in Rome, Journal of Regional Science, WP 1208 (February 2019).

COVA P., P. PAGANO, A. NOTARPIETRO and M. PISANI, Secular stagnation, R\&D, public investment and monetary policy: a global-model perspective, Macroeconomic Dynamics, WP 1156 (December 2017).

DEL PRETE S. and S. FEDERICO, Do links between banks matter for bilateral trade? Evidence from financial crises, Review of World Economics, WP 1217 (April 2019).

Fidora M., C. GIORDANO and M. SCHMITZ, Real exchange rate misalignments in the Euro Area, Open Economies Review, WP 1162 (January 2018).

Gerali A. and S. Neri, Natural rates across the Atlantic, Journal of Macroeconomics, WP 1140 (September 2017).

Li F., A. MercatAnti, T. MAKINEN and A. SiLVESTRINI, A regression discontinuity design for ordinal running variables: evaluating central bank purchases of corporate bonds, Annals of Applied Statistics, WP 1213 (March 2019).

LiberATI D. and M. LOBERTO, Taxation and housing markets with search frictions, Journal of Housing Economics, WP 1105 (March 2017).

Loschiavo D., Household debt and income inequality: evidence from Italian survey data, Review of Income and Wealth, WP 1095 (January 2017).

METELli L. and F. NATOLI, The international transmission of US tax shocks: a proxy-SVAR approach, IMF Economic Review, WP 1223 (June 2019).

Mocetti S., G. RomA and E. RubOLINO, Knocking on parents' doors: regulation and intergenerational mobility, Journal of Human Resources, WP 1182 (July 2018).

MOdENA F., E. RETTORE and G. M. TANZI, The effect of grants on university dropout rates: evidence from the Italian case, Journal of Human Capital, WP 1193 (September 2018).

NiSPI LANDI V. and A. SCHIAVONE, The effectiveness of capital controls, Open Economies Review, WP 1200 (November 2018).

Pereda Fernandez S., Copula-based random effects models for clustered data, Journal of Business \& Economic Statistics, WP 1092 (January 2017).

PERICOLI M., On risk factors of the stock-bond correlation, International Finance, WP 1198 (November 2018).

Pericoli M. and M. TABOGA, Nearly exact Bayesian estimation of non-linear no-arbitrage term-structure models, Journal of Financial Econometrics, WP 1189 (September 2018).

RAINONE E., The network nature of otc interest rates, Journal of Financial Markets, WP 1022 (July 2015). 